\title{
Accumulation of aerosols over the Indo-Gangetic plains and southern slopes of the Himalayas: distribution, properties and radiative effects during the $\mathbf{2 0 0 9}$ pre-monsoon season
}

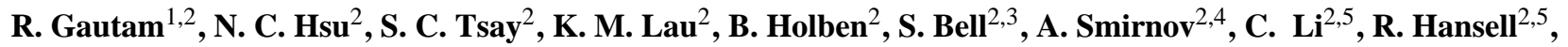

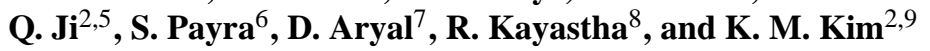 \\ ${ }^{1}$ GESTAR/Universities Space Research Association, Columbia, MD 21044, USA \\ ${ }^{2}$ NASA Goddard Space Flight Center, Greenbelt, MD 20771, USA \\ ${ }^{3}$ Science Systems and Applications, Inc., Lanham, MD 20706, USA \\ ${ }^{4}$ Sigma Space Corporation, Lanham, MD 20706, USA \\ ${ }^{5}$ Earth System Science Interdisciplinary Center, University of Maryland, College Park, MD 20742, USA \\ ${ }^{6}$ Birla Institute of Technology Mesra, Extension Centre - Jaipur, Jaipur, India \\ ${ }^{7}$ Tribhuwan University, Kathmandu, Nepal \\ ${ }^{8}$ Kathmandu University, Dhulikhel, Nepal \\ ${ }^{9}$ GESTAR/Morgan State University, Baltimore, MD 21251, USA
}

Received: 21 April 2011 - Published in Atmos. Chem. Phys. Discuss.: 23 May 2011

Revised: 24 October 2011 - Accepted: 8 December 2011 - Published: 20 December 2011

\begin{abstract}
We examine the distribution of aerosols and associated optical/radiative properties in the Gangetic-Himalayan region from simultaneous radiometric measurements over the Indo-Gangetic Plains (IGP) and the foothill/southern slopes of the Himalayas during the 2009 pre-monsoon season. Enhanced dust transport extending from the Southwest Asian arid regions into the IGP, results in seasonal mean (April-June) aerosol optical depths of over 0.6 - highest over Southern Asia. The influence of dust loading is greater over the Western IGP as suggested by pronounced coarse mode peak in aerosol size distribution and spectral single scattering albedo (SSA). Transported dust in the IGP, driven by prevailing westerly airmass, is found to be more absorbing $\left(\mathrm{SSA}_{550 \mathrm{~nm}}<0.9\right)$ than the near-desert region in Northwestern (NW) India suggesting mixing with carbonaceous aerosols in the IGP. On the contrary, significantly reduced dust transport is observed over eastern IGP and foothill/elevated Himalayan slopes in Nepal where strongly absorbing haze is prevalent, as indicated by lower SSA (0.85-0.9 at 440-1020 nm), suggesting presence of more absorbing aerosols compared to IGP. Additionally, our observations show a distinct diurnal pattern of aerosols with charac-
\end{abstract}

Correspondence to: R. Gautam

(ritesh.gautam@nasa.gov)

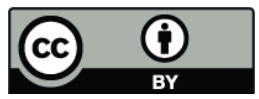

teristic large afternoon peak, from foothill to elevated mountain locations, associated with increased upslope transport of pollutants - that likely represent large-scale lifting of absorbing aerosols along the elevated slopes during pre-monsoon season. In terms of radiative impact of aerosols, over the source region of NW India, diurnal mean reduction in solar radiation fluxes was estimated to be $19-23 \mathrm{Wm}^{-2}$ at surface (12-15\% of the surface solar insolation). Furthermore, based on limited observations of aerosol optical properties during the pre-monsoon period and comparison of our radiative forcing estimates with published literature, there exists a general spatial heterogeneity in the regional aerosol forcing, associated with the absorbing aerosol distribution over northern India, with both diurnal mean surface forcing and forcing efficiency over the IGP exceeding that over Northwestern India. Finally, the role of the seasonal progressive buildup of aerosol loading and water vapor is investigated in the observed net aerosol radiative effect over Northwestern India. The radiative impact of water vapor is found to amplify the net regional aerosol radiative forcing suggesting that the two exert forcing in tandem leading to enhanced surface cooling. It is suggested that water vapor contribution should be taken into account while assessing aerosol forcing impact for this region and other seasonally similar environments.

(ritesh.gautam@ nasa.gov)

Published by Copernicus Publications on behalf of the European Geosciences Union. 


\section{Introduction}

Aerosols over South Asia have received growing attention in recent years due to their potential effects on the seasonal evolution and long-term variability of the summer monsoon, as demonstrated by climate modeling studies (Menon et al., 2002; Ramanathan et al., 2005; Lau et al., 2006; Meehl et al., 2008; Randles and Ramaswamy, 2008; Collier and Zhang, 2009; Sud et al., 2009; Wang et al., 2009). Effects of aerosol solar absorption, causing atmospheric warming and surface cooling, have been demonstrated to influence the monsoon rainfall distribution over the South Asian region, which largely is responsible for sustaining the agrarian economy and livelihood of a large population base. Together with the summer monsoon, meltwater from the glaciers in the Himalayas also constitute a significant component of the regional hydrological resource. Accelerated snow melt due to aerosol deposition (Ming et al., 2008; Yasunari et al., 2010; Qian et al., 2011) and aerosol-induced warming (Ramanathan et al., 2008; Lau et al., 2010; Qian et al., 2011) over the snow surface, also underscores the role of absorbing aerosols in influencing the hydrological cycle of the overall South Asian region from the elevated and sparsely inhabited Himalayas to the densely populated flat-lying plains of the Indus-Ganges river basin.

The pre-monsoon season (April through early June) is the key period when aerosol loading peaks over the IndoGangetic Plains (IGP) as well as over the elevated slopes of the Himalayas (Pant et al., 2006; Gobbi et al., 2010; Bonasoni et al., 2010; Marinoni et al., 2010; Ram et al., 2010). Fraught with high levels of anthropogenic emissions, aerosol distribution in terms of type and loading undergo strong variability associated with the episodic yet strong influence of dust transport and biomass burning during the pre-monsoon period. The prevailing westerly airmass causes large influx of mineral aerosol, originating over the arid regions of Southwest Asia from the Arabian Peninsula to the Thar Desert, which is further mixed with anthropogenic emissions in the IGP. Ground-based radiometric and in-situ observations have clearly indicated the strong seasonal variation of aerosol loading and changes in aerosol properties both over the IGP (Singh et al., 2004; Dey et al., 2004; Prasad and Singh, 2007; Beegum et al., 2008; Pandithurai et al., 2008; Gautam et al., 2009a, 2010; Soni et al., 2010; Eck et al., 2010; Giles et al., 2011) and the southern slopes of the Himalayas (Pant et al., 2006; Beegum et al., 2008; Dumka et al., 2010; Bonasoni et al., 2010; Decesari et al., 2010; Gobbi et al., 2010; Ram et al., 2010). The critical role of transported dust in influencing aerosol optical properties is systematically observed in episodic events (Hegde et al., 2006) as well as in the intra-seasonal variability (Hyvarinen et al., 2009; Kompulla et al., 2009; Marinoni et al., 2010; Ram et al., 2010) at a few locations in the Himalayan region. Influx and accumulation of aerosols over northern and central India extends to elevated altitudes (above 3-4 km) (Gautam et al., 2010; Kuhlmann and Quass, 2010; Kar et al., 2010) and can be transported above the boundary layer clouds leading to enhanced absorption of solar radiation and regional warming (Satheesh et al., 2008). Mixed with heavy loadings of carbonaceous aerosols over northern India, mineral dust can potentially induce changes in the regional atmospheric circulation thereby redistributing the summer monsoon rainfall via the so-called Elevated Heat Pump mechanism (Lau et al., 2006; Lau and Kim, 2006). Recent observational works have also investigated possible feedbacks between aerosol-monsoon coupling via analysis of inter-annual variations and long-term trends of aerosol loading, rainfall and tropospheric temperatures, during pre-monsoon season (Lau and Kim, 2006, 2011; Bollasina et al., 2008; Gautam et al., 2009b, c). The radiative-dynamical process is therefore a key underlying mechanism towards assessing the associated aerosol impacts on the regional hydrological cycle.

Several aforementioned ground-based studies have provided key aerosol information over single point locations in the Gangetic-Himalayan region in terms of episodic and seasonal changes in aerosol optical and radiative properties. However, aerosol characterization along the GangeticHimalayan region, i.e. from west to east and also from south to north of the vast complex domain, is required for the better understanding of regional aerosol distribution and radiative effects in order to quantify absorbing aerosol distribution along the southern edge of the Himalayas and their effects on the cryospheric reservoirs and monsoon circulation, as laid out by Lawrence and Lelieveld (2010; see for a review). In this paper, we report simultaneous aerosol and broadband surface flux measurements over the IndoGangetic Plains (IGP) and southern slopes of the Himalayas during the pre-monsoon season of 2009, as part of the Radiation Aerosol Joint Observations - Monsoon Experiment in the Gangetic Himalayan Area (RAJO-MEGHA). The RAJO-MEGHA field deployment was organized under the Joint Aerosol Monsoon Experiment (JAMEX, see Lau et al., 2008) and coordinated with the Aerosol Robotic Network's (AERONET, see Holben et al., 1998) measurements from the existing network of sunphotometers in the IGP. This paper presents ground-based radiometric assessment of aerosol optical/radiative properties and regional distribution with an emphasis on the spatial variations from the flat plains to the elevated slopes of the Gangetic-Himalayan region. Simultaneous measurements in northern India and Nepal were carried out to characterize the aerosol loading and understand the variability of optical properties including aerosol size distribution, single scattering albedo (SSA), along with water vapor dynamics, during the course of the pre-monsoon season. The regional direct aerosol radiative effect is estimated along with the investigation of the role of seasonal progression of aerosol loading and water vapor in the observed net aerosol forcing over Northwestern India. Observational results from this paper are anticipated to enhance the overall knowledge of the regional aerosol distribution as well as 
solar absorption that can assist modeling community to better constrain numerical experiments in studying the sensitivity of atmospheric circulation to absorbing aerosols related to the investigation of aerosol-monsoon rainfall coupling. Additionally, a unified network of column-integrated aerosol measurements also aid in the better understanding of localto-regional aerosol characteristics in relation with validation and potential improvement of satellite-retrieved aerosol products (e.g. from MODIS, MISR) that have been shown to have relative biases over northern India and Nepal region (Jethva et al., 2007; Kahn et al., 2009, 2010). The uniqueness of the data collected from the campaign is also an important aspect of the paper as the comprehensive dataset follows similar instrumentation and calibration protocols across the AERONET sunphotometer, Microtops and pyranometer measurements over northern India and Nepal during the premonsoon season. Figure 1 shows locations of the measurement sites over northern India and Nepal encompassing the near-dust source region, the IGP and the southern slopes of the Himalayas where radiometric measurements using handheld and automatic sunphotometers, and pyranometers were conducted during April-June 2009. Measurements from existing AERONET sunphotometers are also included in the analysis, which help us to portray the regional absorbing aerosol distribution. As evident from Fig. 1 and per our underlying rationale, measurement sites were selected to represent the west-east and south-north transects. Table 1 lists the various site locations with their coordinate and elevation information.

\section{Datasets and methodology}

\subsection{Ground-based sunphotometry and broadband radiometry}

We use version 2 retrievals (Dubovik et al., 2006; Holben et al., 2006) of aerosol optical properties derived from CIMEL sunphotometer measurements, as part of the AERONET, in this paper. Sunphotometers were installed at Jaipur, an urban location in Northwestern India near the western edge of Thar Desert as well as at Hetauda (foothill station), Kathmandu University at Dhulikhel (1500 m a.s.l.) and at Langtang (high altitude mountain slope, $3670 \mathrm{~m}$ a.s.l.) in Nepal. The direct sun measurements are made at seven spectral channels from 340 to $1020 \mathrm{~nm}$ for Aerosol Optical Depth (AOD) retrievals with the $940 \mathrm{~nm}$ channel used for retrieving column Water Vapor (WV). In addition, sky radiance measurements at four spectral channels $(440,670,870$, and $1020 \mathrm{~nm})$ are used to retrieve aerosol volume size distribution and SSA. Data from other existing sunphotometers in the IGP, namely Gual Pahari (25 km southwest of Delhi), Kanpur, Gandhi College and are also presented in the paper. Quality assured Level 2 data were used in the paper for all sites.
In addition to automatic CIMEL sunphotometers, we also used a number of handheld Microtops II sunphotometers (manufactured by Solar Light Co., USA). The handheld sunphotometers are easy-to-operate portable instruments which when used accurately; provide highly useful information about aerosol loading and column abundance of ozone and water vapor. For this study, sunphotometers with the capability of AOD and WV measurements were used. Microtops sunphotometers are equipped with five channels, i.e. four pertaining to column aerosol measurements and one corresponding to water vapor absorption channel $(936 \mathrm{~nm})$. Microtops can be quite accurate and stable, with root-meansquare differences between corresponding retrievals from clean calibrated Microtops and the AERONET Sunphotometer being about \pm 0.02 at $340 \mathrm{~nm}$, decreasing down to about \pm 0.01 at $870 \mathrm{~nm}$ (Ichoku et al., 2002). The estimated uncertainty of AOD in each channel does not exceed plus or minus 0.02 , which is slightly higher than the uncertainty of the AERONET field instruments as shown by Eck et al. (1999) and Smirnov et al. (2009).

The operation protocol, calibration procedure and cloudscreening for the Microtops, during the field measurements, followed the methodology of the Marine Aerosol Network (Smirnov et al., 2009), in close adherence to the AERONET data processing (Smirnov et al., 2000). Each Microtops unit was cross-calibrated (pre- and post-field deployment) against a reference AERONET sunphotometer at NASA/Goddard Space Flight Center, which is calibrated from morning Langley plot measurements at Mauna Loa. About 20-30 consecutive scans were taken on Microtops within an approximately 5-6 min interval, collocated with the CIMEL. These cross-calibration measurements were made in relatively clear (with AOD at $500 \mathrm{~nm}$ less than 0.2) and stable atmospheric conditions to ensure accurate results. The AOD was retrieved by applying the AERONET processing algorithm to the raw data (Smirnov et al., 2004; also see http://aeronet.gsfc.nasa. gov/new_web/Documents/version2_table.pdf).

A strict measurement protocol was followed for the handheld sunphotometer at all sites to ensure the highest quality data collected and also to avoid any potential cloud contamination. The protocol is quite simple, yet effective, and requires an operator taking 5-6 consecutive scans (slightly over a minute to complete the sequence) when the solar disk is visibly free of clouds. Our measurement period benefitted due to the relatively dry pre-monsoon season. Depending on sky conditions, measurements were made several times during the day. In general, efforts were made to have measurements at a continuous interval of 30-60 min, in order to acquire adequate sample size as well as to characterize the diurnal aerosol loading. Over Jaipur, both CIMEL and Microtops were co-located in order to make inter-comparison between the two instruments as well as to determine the quality of handheld measurements. Inter-comparison plots of AOD at four wavelengths namely, $340 \mathrm{~nm}, 440 \mathrm{~nm}, 500 \mathrm{~nm}$ and $870 \mathrm{~nm}$ retrieved from the 
Table 1. Mean values (and standard deviation) of Aerosol Optical Depth, Angstrom Exponent and Water Vapor, for the measurement period during 2009, over various measurement sites at near-Desert (Jaipur), Indo-Gangetic Plains (Gual Pahari, Kanpur, Gandhi College) and foothill/slope stations (Chitkara University, Shimla, Hetauda, Dhulikhel and Langtang). Site information including coordinate and elevation is also listed for each site.

\begin{tabular}{llrlrrr}
\hline Site & $\begin{array}{l}\text { Location } \\
\text { Coordinates }\end{array}$ & Elev. $(\mathrm{m})$ & $\begin{array}{l}\text { AOD } \\
(500 \mathrm{~nm})\end{array}$ & $\begin{array}{l}\text { Angstrom } \\
\text { Exponent }\end{array}$ & $\begin{array}{l}\text { Water Vapor } \\
(\mathrm{cm})\end{array}$ & $\begin{array}{r}\text { Measurement } \\
\text { period (2009) }\end{array}$ \\
\hline Jaipur & $26.90^{\circ} \mathrm{N}, 75.80^{\circ} \mathrm{E}$ & 450 & $0.46 \pm 0.17$ & $0.31 \pm 0.19$ & $2.02 \pm 0.82$ & $3 \mathrm{Apr}-16 \mathrm{Jun}$ \\
Chitkara & $30.86^{\circ} \mathrm{N}, 76.86^{\circ} \mathrm{E}$ & 520 & $0.57 \pm 0.25$ & $0.72 \pm 0.28$ & $1.8 \pm 0.65$ & $11 \mathrm{Apr}-16 \mathrm{Jun}$ \\
Shimla & $31.08^{\circ} \mathrm{N}, 77.18^{\circ} \mathrm{E}$ & 2100 & $0.33 \pm 0.18$ & $0.87 \pm 0.34$ & $0.99 \pm 0.36$ & $7 \mathrm{Apr}-16 \mathrm{Jun}$ \\
Gual Pahari & $28.42^{\circ} \mathrm{N}, 77.15^{\circ} \mathrm{E}$ & 384 & $0.64 \pm 0.24$ & $0.52 \pm 0.27$ & $2.2 \pm 0.85$ & $1 \mathrm{Apr}-16 \mathrm{Jun}$ \\
Kanpur & $26.51^{\circ} \mathrm{N}, 80.23^{\circ} \mathrm{E}$ & 123 & $0.61 \pm 0.22$ & $0.57 \pm 0.32$ & $2.51 \pm 1.01$ & $1 \mathrm{Apr}-16 \mathrm{Jun}$ \\
Gandhi College & $25.87^{\circ} \mathrm{N}, 84.12^{\circ} \mathrm{E}$ & 60 & $0.60 \pm 0.23$ & $0.77 \pm 0.32$ & $3.2 \pm 1.56$ & $1 \mathrm{Apr}-16 \mathrm{Jun}$ \\
Hetauda & $27.42^{\circ} \mathrm{N}, 85.03^{\circ} \mathrm{E}$ & 465 & $0.75 \pm 0.50$ & $1.10 \pm 0.27$ & $2.64 \pm 0.91$ & $18 \mathrm{Apr}-30 \mathrm{May}$ \\
Dhulikhel & $27.61^{\circ} \mathrm{N}, 85.53^{\circ} \mathrm{E}$ & 1500 & $0.73 \pm 0.49$ & $1.23 \pm 0.36$ & $1.49 \pm 0.53$ & $11 \mathrm{Apr}-16 \mathrm{Jun}$ \\
Langtang & $28.01^{\circ} \mathrm{N}, 85.49^{\circ} \mathrm{E}$ & 3670 & $0.35 \pm 0.31$ & $1.40 \pm 0.38$ & $0.34 \pm 0.14$ & $24 \mathrm{Apr}-10 \mathrm{May}$ \\
\hline
\end{tabular}

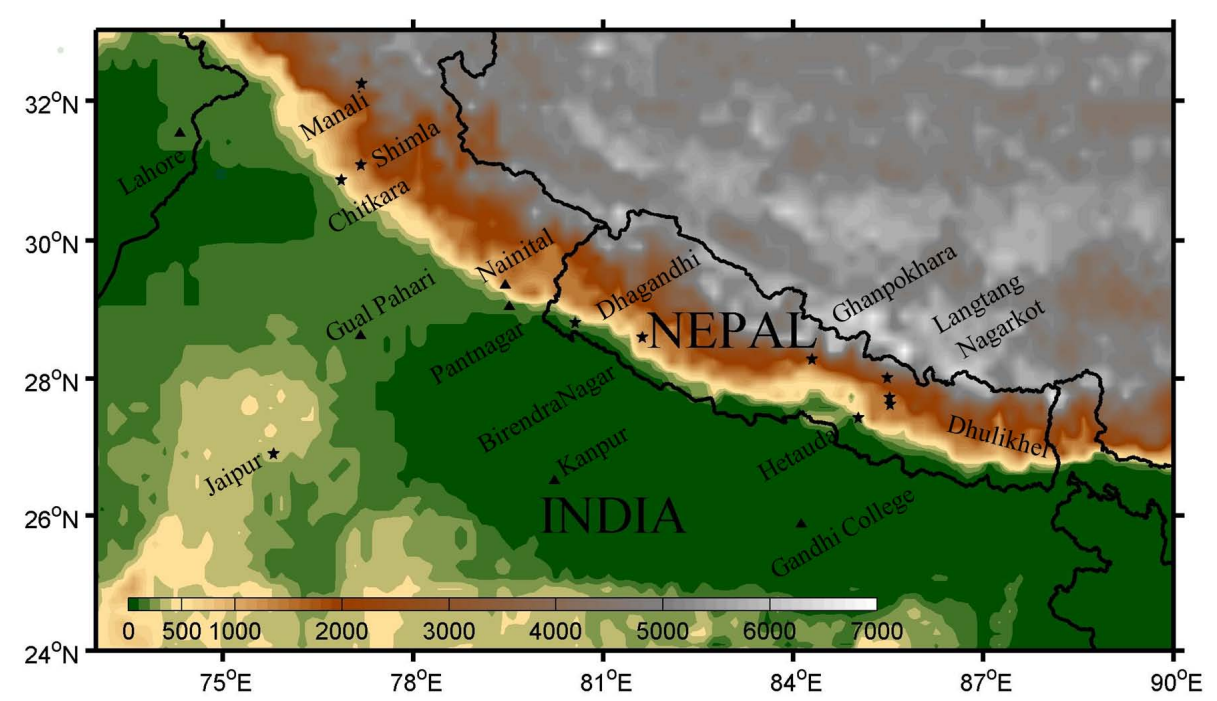

Fig. 1. Major sites of RAJO-MEGHA (stars) with AERONET sunphotometer (triangles) deployments during April-May-June 2009 over northern India and Nepal. Background shading represents elevation in $\mathrm{m}$ a.s.l.

CIMEL and Microtops sunphotometer are shown in Fig. 2. The entire set of all temporally co-located instantaneous retrievals within \pm 15 min were used for the inter-comparison. There is a slight overestimation in the Microtops-retrieved AOD values as indicated by the slope of the linear regression at the four channels (slope values ranging from 1.0057 to 1.0496) which could be attributed to the inherent uncertainty in the instrument and/or to pointing error by the operator. Overall, the inter-comparison shows close agreement between the two measurements as indicated by the high correlation ( $r^{2}$ values) and the linear fit between the retrieved $\mathrm{AOD}$, thus providing confidence in the operation and quality of the handheld measurements.

Broadband surface flux measurements from pyranometers are also used in this paper to assess the direct aerosol radia- tive effect at surface. In this paper, surface flux data shown at two locations namely, Jaipur and Chitkara University, are obtained from pyranometers measuring global flux (direct plus diffuse) in the $0.3 \mu \mathrm{m}-3 \mu \mathrm{m}$ shortwave spectrum thus covering the broadband shortwave flux. The pyranometers were co-located with the handheld/automatic CIMEL sunphotometers and recorded instantaneous downwelling irradiance at $10 \mathrm{~s}$ intervals. Instantaneous flux measurements were subjected to a cloud screening procedure similar to the methodology of Schafer et al. (2002), wherein a time variability filter was required to eliminate scattered and peripheral clouds in the hemispherical field-of-view. A preprocessing step was introduced to average the high frequency data stream to a 2 min interval dataset in order to reduce the noise. Flux measurements temporally co-located with 


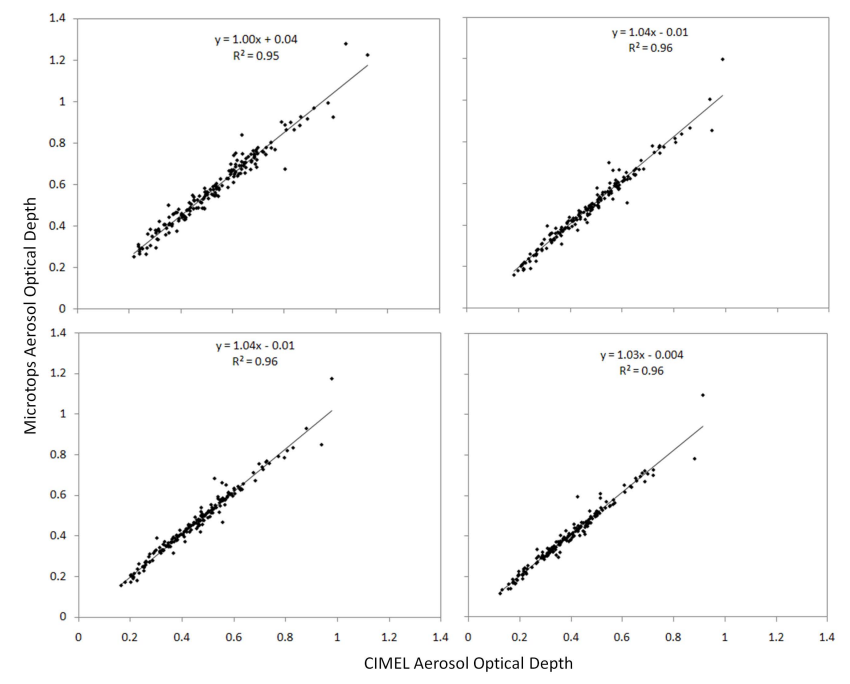

Fig. 2. Inter-comparison of co-located measurements of Aerosol Optical Depth from automatic and handheld sunphotometers over Jaipur. Scatter plots show the entire set of all temporally co-located instantaneous retrievals within $\pm 15 \mathrm{mn}$ from the two instruments at four wavelengths namely, $340 \mathrm{~nm}, 440 \mathrm{~nm}, 500 \mathrm{~nm}$ and $870 \mathrm{~nm}$.

concurrent sunphotometer measurements within a $\pm 2 \mathrm{~min}$ time frame were selected for further analysis. In addition, to further minimize passing cloud influence, 3 -continuous measurements from the sunphotometer (about $30-45 \mathrm{~min}$ ), were selected to represent the time window deemed as cloud-less.

\subsection{Satellite measurements from Terra/Aqua MODIS data}

Level 2 Aqua/MODIS aerosol products (Collection 5.1, or C5.1), namely Dark-Target (Remer et al., 2005; Levy et al., 2007) and Deep Blue (Hsu et al., 2004, 2006), were used in the paper to show the regional aerosol loading. The C5.1 Dark-Target aerosol algorithm is an improvement over the previous MODIS aerosol retrieval algorithms (Collection 4). Specifically, this new algorithm performs a simultaneous three-channel inversion to make use of aerosol information contained in the shortwave infra-red $(2.12 \mu \mathrm{m})$ channel. However, the data show gaps over bright surfaces such as deserts and arid regions. Therefore, in addition to the DarkTarget aerosol product, MODIS Deep Blue AOD was used that includes global aerosol information over land including, but not limited to, bright surfaces. The Deep Blue aerosol retrievals are also available from the MODIS C5.1 dataset. Both the level-2 MODIS AOD data were averaged for each pixel and were binned into a quarter degree uniform spatial grid in order to represent the composite aerosol loading over the Indian subcontinent for each month. The usage of combined aerosol products is to qualitatively show the progression of pre-monsoon aerosol loading from the source arid regions into the IGP region. Quantitative analysis through- out the paper including radiative forcing is carried out using aerosol properties obtained from sunphotometer retrievals.

\subsection{MERRA data}

Total column precipitable water and wind fields (at $850 \mathrm{mb}$ ), obtained from NASA's Modern Era Retrospective-Analysis For Research and Applications (MERRA) data, was used to demonstrate the spatio-temporal variations and seasonal migration of atmospheric water vapor, associated with the dynamical background over India and adjacent oceanic regions. The MERRA dataset is a new reanalysis product for the satellite era based on GEOS-5 climate model and data assimilation system, developed with a goal to improve the hydrological cycle (Rienecker et al., 2011). For atmospheric water vapor, major sources of data assimilation are radiosonde observations. The assimilation system also includes instantaneous rain rate estimates from satellite-derived SSM/I and the TRMM TMI data, and moisture-sensitive radiance data from SSM/I and AMSU-B (Rienecker et al., 2008, 2011). MERRA water vapor has been compared/validated with other reanalysis (Rienecker et al., 2011), SSM/I (Rienecker et al., 2011), AIRS (Wong et al., 2011) and in situ observations (Kennedy et al., 2011). It should be noted that MERRA water vapor data is not used for quantitative analysis in this paper. Sunphotometer-retrieved column water vapor measurements over the surface sites are used for radiative forcing calculations.

\subsection{Radiative transfer model}

We used a 1-dimensional radiative transfer model (RTM) for plane-parallel atmospheres (Fu and Liou, 1993), to estimate aerosol radiative effects at surface during pre-monsoon season. The shortwave spectrum $(0.2-4.0 \mu \mathrm{m})$ is divided into 6 bands: $0.2-0.7,0.7-1.3,1.3-1.9,1.9-2.5,2.5-3.5$, and $3.5-4.0 \mu \mathrm{m}$. For this study, the last shortwave-IR band (3.5$4.0 \mu \mathrm{m}$ ) was not included in RTM calculations as it is outside the range of the pyranometer's spectrum. The radiative effects of Rayleigh scattering, continuum absorption of WV and surface albedo are also considered in the model. The inputs to model calculation include AOD and water vapor obtained from sunphotometer measurements. Aerosol optical model consisted of an external mixture of dust, water soluble species and soot, which were mixed iteratively until a close agreement was achieved between the calculated flux and observations. A mid-latitude summer atmosphere profile was selected in the model but was adjusted to correct for the surface elevation above mean sea level. Vertical distribution of aerosols was provided to the model based on spaceborne CALIPSO aerosol extinction profile for the period 15 March -15 June averaged over a $2^{\circ} \times 2^{\circ}$ box centered over Jaipur and Chitkara (shown in Supplement Fig. S1). A fixed mean profile was provided as input to the RTM to calculate diurnally averaged radiative forcing. A slightly longer period 
was chosen (from 15 March onwards) as well as a multiyear composite (2007-2010) was generated to have a larger sample size due to the sparse availability of CALIPSO profiles. Surface albedo input to the model was provided as a broadband value obtained from the CERES-derived broadband surface albedo product that has been inter-compared with MODIS albedo product, with a relative difference reported as $2.1 \%$ between the two datasets (Rutan et al., 2009). The monthly mean CERES-derived surface albedo for Jaipur and Chitkara were in the range $0.18-0.21$ during the AprilMay period and therefore a fixed mean value was provided as input to the RTM. The sensitivity of surface solar flux to surface albedo is quite small with a maximum value of $\pm 1.5 \%$ for the broadband surface albedo range of $0.15-0.25$ (see Sect. 5.1 for details of uncertainty in radiative forcing estimation). The model calculation also included adjustments to AOD and water vapor profile depending on the surface elevation. Additionally, the water vapor profile in the model was linearly scaled to match the column integrated observed amounts from CIMEL on an instantaneous measurements basis. Here, the methodology followed for model inputs and calculations in this paper is similar to our previous aerosol radiative forcing estimation over Kanpur (Gautam et al., 2010). More details about the selected external aerosol mixture model for this study and comparison between modeled and observed surface fluxes is given in Sect. 5 .

\section{Regional aerosol distribution and meteorology}

Several satellite-based studies indicate the IGP as a major pollution hot spot due to dust transport, anthropogenic aerosols and biomass burning during pre-monsoon season (Jethva et al., 2005; Habib et al., 2006; Gautam et al., 2009b, 2010; Dey and Di Girolamo, 2010; Kaskaoutis et al., 2011). In contrast to the winter season which is characterized by dense haze and dominated by fine-mode aerosols, the transition from winter to pre-monsoon season signals the enhanced influx of desert dust over northern India from April to June. With the onset of summer monsoon rainfall, significant reduction in AOD occurs due to wet removal of aerosols from the atmosphere.

Figure 3 shows the spatial distribution of MODIS AOD for April, May and June during 2009. A progressive buildup and increase in aerosol loading is clearly visible over northern India, associated with enhanced dust transport from the Thar Desert into the IGP and Himalayan foothill region during the pre-monsoon season. Due to the influx of westerly wind-blown mineral dust, there is a nearly twofold increase in the net column aerosol loading over the IGP region from April (0.5-0.7) to May (0.7-1). In addition, a marked increase in AOD is observed over the northern Arabian Sea, also associated with the predominant westerly airmass transport from the arid regions of the Arabian Peninsula. The higher AOD $(\sim 0.5)$ over Northern Arabian Sea is in sharp contrast with the substantially lower over the Southern Arabian Sea and Northern Indian Ocean. The north-south contrast is typical to the Arabian Sea aerosol distribution during the pre-monsoon season as previously shown by shipborne measurements (Satheesh and Srinivasan, 2002; Kalapureddy et al., 2009; Kaskaoutis et al., 2010). Similar aerosol loading pattern exists over the Indian subcontinent, in general, with a stronger gradient from north to south.

The aerosol loading pattern is consistent with the regional prevailing meteorology such that the persistent high AOD regions in Northwestern India and other southwest Asian arid regions are also the driest areas in terms of both water vapor and rainfall. Figure 4 (top panel) shows the monthly mean WV obtained from MERRA data for April, May and June 2009. Northern regions of India and Arabian Sea are associated with substantially lower water vapor $(<<30 \mathrm{~mm}) \mathrm{com}-$ pared to Southern India, Indian Ocean and Bay of Bengal. Similar to the AOD monthly variation, WV also increases substantially from April $(<20 \mathrm{~mm})$ through June $(\gg 30 \mathrm{~mm})$, albeit the regional distribution of water vapor remains similar to April with lower moisture influx over Southwest Asia compared to the rest of the subcontinent and oceanic regions. As the monsoon season approaches around June, with the deepening of the Bay of Bengal depression, enhancement in $\mathrm{WV}$ is noted over the eastern IGP associated with the Bay of Bengal branch of the summer monsoon resulting in values exceeding $40 \mathrm{~mm}$. Higher values of WV are also seen over the Western Ghats during this period indicating the onset of rainy season.

Additionally, the elevated Himalayas and Tibetan Plateau are characterized by prevalent dry airmass. The southern edge of the Himalayas forms a barrier for the winds carrying moisture as shown in the WV distribution indicating the lack of moisture transport in the middle troposphere. Only during June, there is an increase in WV over the eastern Tibetan Plateau which is associated with the large-scale circulation feature of the South and East Asian Monsoon that spawns deep convective activity and strong updrafts in the middleupper levels of the troposphere. In terms of rainfall, the southern coast of India received the pre-monsoon showers as early as in April as seen in the TRMM-observed rainfall rate for April (Fig. 4, bottom panel). With the onset of monsoon in June, the most pronounced rainfall occurs over the Western Ghats, Northeastern India and Bay of Bengal in values exceeding $15 \mathrm{~mm} \mathrm{day}^{-1}$. Modest increase in rainfall is also observed over the foothills and lower slopes of the Himalayas in the central-eastern fringe indicating moist convection in June relative to April. On the other hand, Northwestern India and adjacent arid regions largely remained dry and received little rainfall during the entire measurement period further reinforcing the persistence of regional high AOD. 

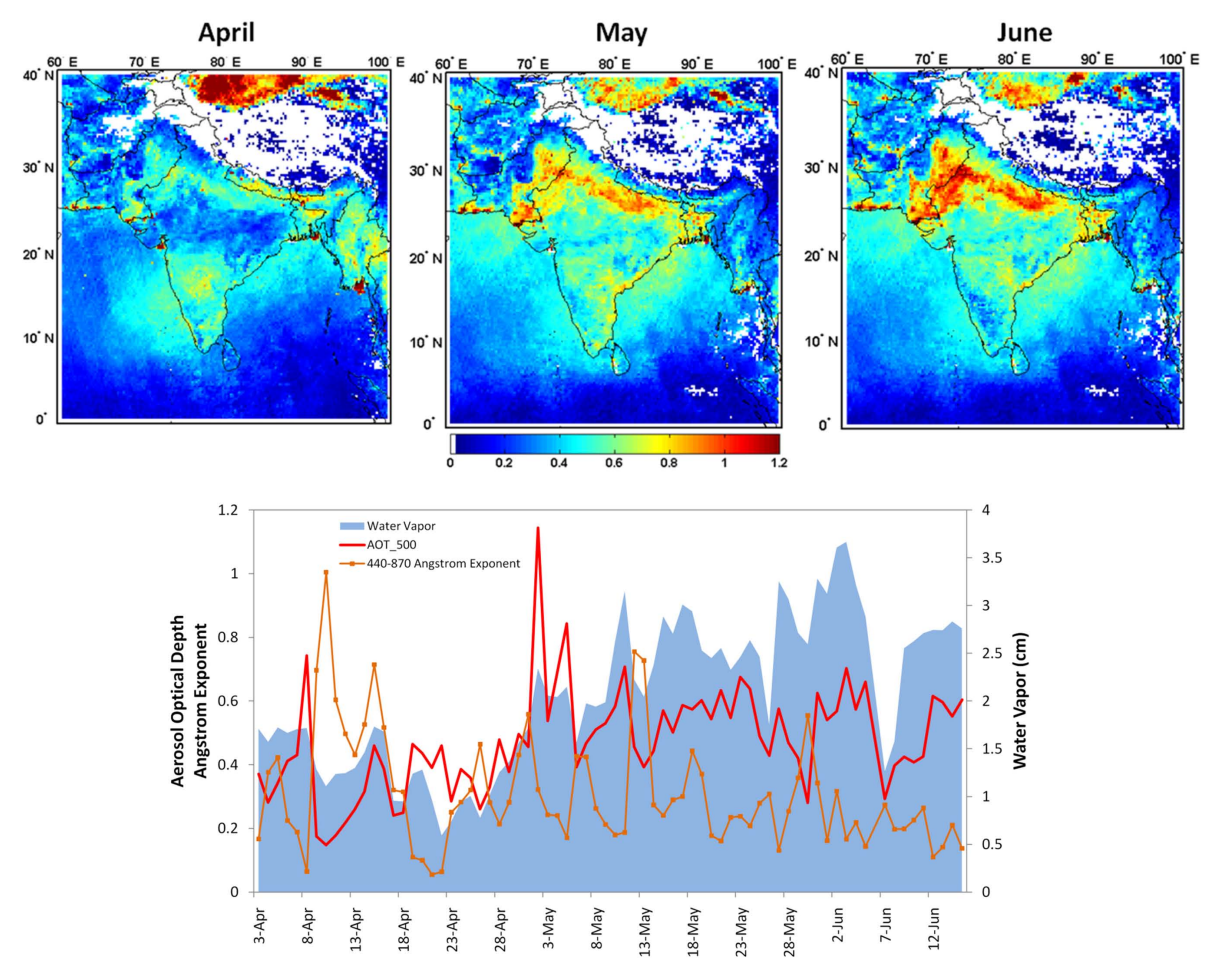

Fig. 3. (top panel) Monthly mean AOD for April, May and June 2009 obtained from daily Level-2 Aqua MODIS aerosol products showing the distribution of aerosol loading over the Indian subcontinent and the progressive increase in AOD over Northern India from April through June, with white shading representing no data (bottom panel). Daily mean variations of AOD at $500 \mathrm{~nm}$, AE for (440-870 nm) and water vapor from CIMEL sunphotometer retrievals over Jaipur from 3 April to 15 June 2009. Monthly mean values during April, May and June for (1) AOD-0.36, 0.57 and 0.6; (2) AE-0.35, 0.31 and 0.19; and (3) WV-1.27, 2.43, $2.73 \mathrm{~cm}$, respectively

\section{Ground-based assessment of aerosol optical properties}

\subsection{Aerosol characterization near dust-source region}

Figure 3 (bottom panel) shows the daily variations of CIMEL sunphotometer retrievals of AOD, Angstrom Exponent (AE), along with WV, from April to June 2009 over Jaipur, i.e. around the western edge of the Thar Desert. Similar to MODIS observations, ground-based sunphotometry also indicates progressive increase in aerosol loading throughout the pre-monsoon period, primarily contributed by the increased mineral dust transport as indicated by the significantly low AE values. The first major dust outbreak over Jaipur was observed on 8 April 2009 with higher AOD (0.76) and low $\mathrm{AE}(0.06)$, respectively. The mean value of $\mathrm{AE}$ for the pre-monsoon period is $\sim 0.3$ with lowest value in June (0.24) indicating an overall dust-dominant period, in general, and during June, in particular. During this period, AOD increased from 0.36 (April mean $_{\text {n }}$ ) to 0.55 (May-June mean $_{\text {) }}$.

The enhanced influx of dust over northern India is not only due to dust emissions over the Thar Desert region but also due to its long-range transport from the Afghanistan/Iran and Middle-Eastern peninsular regions moving eastward over the
Northern Arabian Sea (Prospero et al., 2002; Deepshikha et al., 2006; Satheesh et al., 2006, Prasad and Singh, 2007). Figure 5a shows simulated 5-day airmass trajectories (1500 m a.g.l.) ending at Jaipur (Northwestern India) from 1 to 31 May 2009. The predominant warm and dry westerly airmass that originates over the arid regions of Arabian Peninsula is enriched with moisture as it moves over the northern Arabian Sea before reaching Northwestern India. Together with the increase in dust loading, water path abundance is also found to increase over Jaipur during the AMJ period as shown in the daily variations of WV (Fig. 3). Initial phase of the measurement period is marked by relatively dry airmass with mean WV value of $1.27 \mathrm{~cm}$ during April. The lowest value of WV for the AMJ period is also observed during April (mean value of $0.7 \mathrm{~cm}$ on 22 April 2009). Towards the end of April and during May and June, WV increases significantly as the monsoon season approaches with about twofold increase in WV values (May mean $-2.43 \mathrm{~cm}$ and June $_{\text {mean }}-3 \mathrm{~cm}$ ). Seasonal mean values of AOD, AE and WV over Jaipur and other regions during 2009 are given in Table 1 .

The increased moisture influx is discernible in the scatter plot between AOD and WV (Fig. 6) that shows a systematic increase in aerosol loading relative to water path abundance 

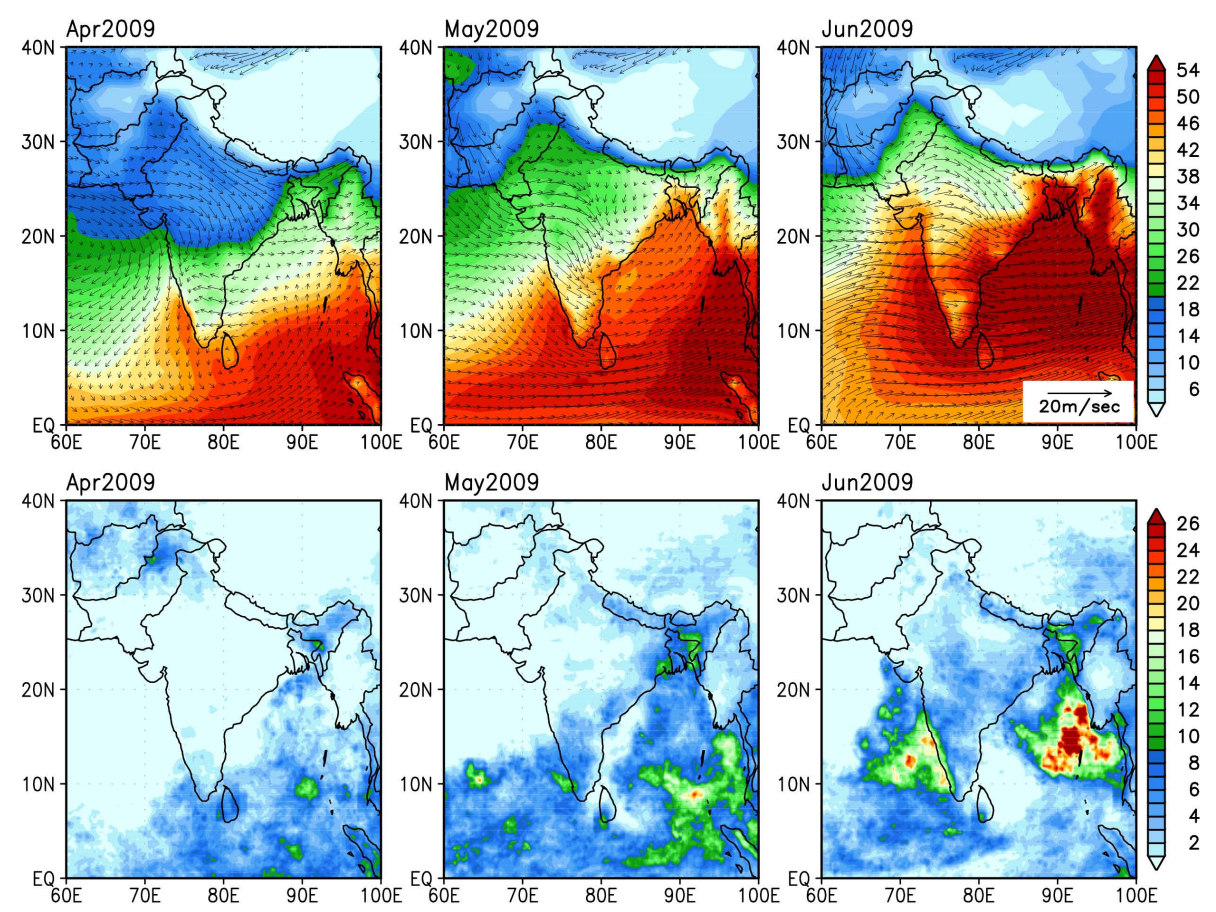

Fig. 4. Monthly mean column water vapor (top panel, unit: $\mathrm{mm}$ ) obtained from MERRA data monthly mean rainfall rate (bottom panel, unit: $\mathrm{mm} \mathrm{day}^{-1}$ ) from TRMM data for April, May and June 2009. Southwest Asian regions remain largely dry during the entire pre-monsoon period while the Western Ghats, Bay of Bengal and Northeastern India show characteristic increase in both the moisture influx and rainfall, most pronounced during the monsoon onset in June 2009.

from the instantaneous direct sun measurements for the AMJ period. The systematic and steady increase in aerosol loading and water vapor is not just specific to Jaipur but is also observed in general over Northwestern India, i.e. over Chitkara, $\sim 350 \mathrm{~km}$ northeast of Jaipur located in the vicinity of the Himalayan foothills and over Shimla (2100 ma.s.1.) northward in the mountain slopes. Here, the increase is more pronounced which can be primarily attributed to the higher frequency of heavy aerosol loading conditions, i.e. AOD greater than 0.8, compared to the range of AOD values observed over Jaipur. Earlier, Bhattacharjee et al. (2007) and Prasad and Singh (2007) also reported enhancement of water vapor with respect to a few dust events over northern India.

On the contrary, sites located in the Eastern Himalayan foothill and slope, in Nepal, show a weak relationship between AOD and WV. Figure 6 (bottom panel) shows scatter plots between AOD and WV over Hetauda (465 m), Dhulikhel $(1500 \mathrm{~m})$ and Langtang $(3670 \mathrm{~m})$ in Nepal. A direct comparison can be made between Chiktara and Hetauda western and eastern foothill locations, respectively, where a close association between the two is found at Chitkara. Unlike the strong relationship at Chitkara $\left(r^{2}-0.64\right)$, data over Hetauda does not show much association between AOD and WV. In addition, a weak association between AOD and WV was also observed over the eastern IGP as indicated by the data from AERONET stations at Gandhi College and
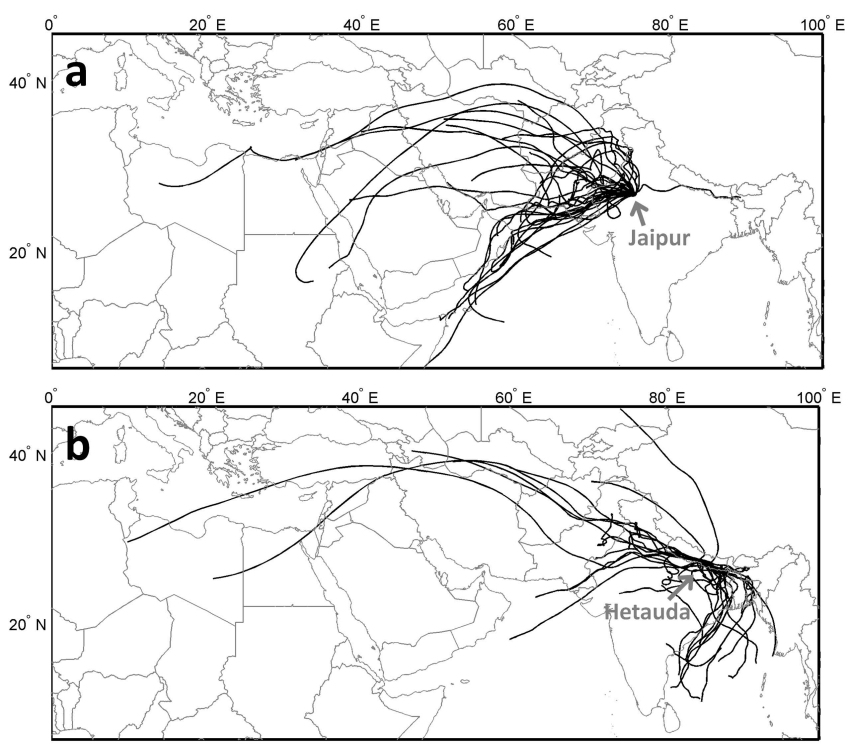

Fig. 5. Five-day backward trajectories of airmass (1500 m above ground level) ending at (a) Jaipur (Northwestern India) and (b) Hetauda (Nepal) from 1-31 May 2009. Note, elevation of Jaipur and Hetauda is $450 \mathrm{~m}$ and $465 \mathrm{~m}$ above mean sea level, respectively. Locations of Jaipur and Hetauda are indicated by arrows. 

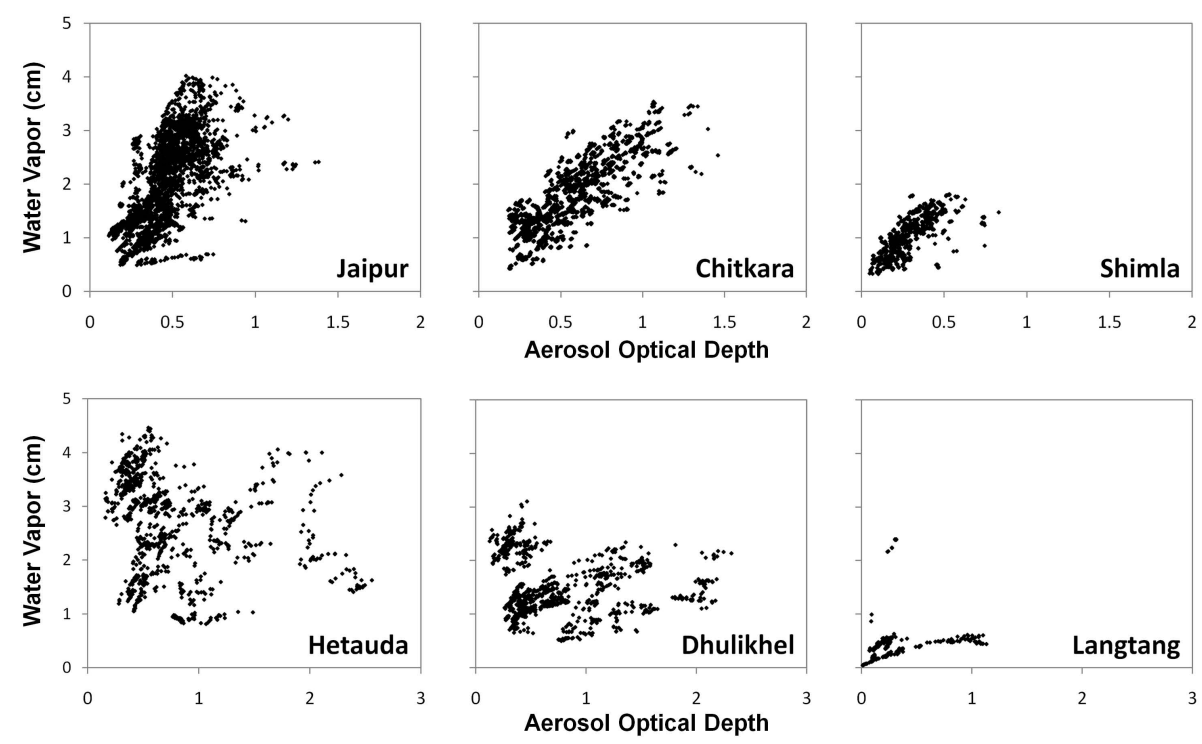

Fig. 6. Scatter plots between AOD and water vapor over Jaipur, Chitkara, Shimla in India (top), and Hetauda, Dhulikhel, Langtang (bottom) for the entire measurement period during the 2009 pre-monsoon season. Data points shown are instantaneous retrievals of AOD and water vapor.

Kolkata (see Supplement Fig. S2). As seen in the $850 \mathrm{mb}$ wind pattern (Fig. 4), the eastern IGP and elevated sites along the southern slopes of the Himalayas (east of $85^{\circ} \mathrm{E}$ ) are influenced by a cyclonic flow centered over Northeastern India in May and June, i.e. typical to the onset of the summer monsoon circulation. The 5-day backward trajectory analysis also supports the observation that a prevailing wind flow over the eastern IGP and adjacent elevated regions may be absent and the region is likely influenced by a mix of airmasses from the Bay of Bengal and Northwestern India as suggested by the airmass ending at Hetauda for 1-31 May 2009 (Fig. 5b). We believe the contrasting association between aerosol loading and moisture influx over Northwestern India and eastern IGP/Nepal, across the west-east domain, is largely governed by the prevailing boundary level westerly airmass over the former, compared to the lack of a prevailing flow over the latter being influenced by a cyclonic-type circulation. Important implications of the simultaneous increase in AOD and WV are discussed in more detail in Sect. 6 in relation with the regional radiative impact at surface.

It should be pointed out here that the relationship between AOD and WV over Northwestern India is not intended to construe any implications regarding the hygroscopicity of aerosols. In fact, aerosol humidification is not likely to play a major role due to the low relative humidity $(\mathrm{RH})$ values over Jaipur as indicated in the surface-based meteorological data in April, May and June where the RH is less than $50 \%$ (see Supplement Fig. S3). For aerosol humidification/swelling effect to take place, the RH is typically over $70-80 \%$ as shown previously in observations (Rood et al., 1987; Kotchenruther et al., 1999). Moreover, dust-dominated environments (gen- erally non-hygroscopic) are not likely to undergo significant humidification, even at high RH values, compared to aerosols comprising water soluble species. Thus, the positive association found between AOD and WV over locations in Northwestern India is a likely manifestation of the predominant westerly airmass that transports dust and is enriched with moisture during the course of the pre-monsoon season.

\subsection{AERONET measurements over the IGP and Himalayan foothills andslopes}

\subsubsection{Aerosol optical properties}

With the characterization of aerosols near the Thar Desert and the dust-dominated column aerosol loading over Northwestern India, we further investigate aerosol loading over the IGP and foothill/slope region, in terms of the size distribution, in order to determine the extent of the dust transport. Here, we show the aerosol volume size distribution from CIMEL sunphotometer over three locations in the IGP - Gual Pahari (on the outskirts of Delhi, $77^{\circ}$ E), Kanpur $\left(80.5^{\circ} \mathrm{E}\right)$ and Gandhi College $\left(84.5^{\circ} \mathrm{E}\right)$ as well as over Jaipur for the 2009 AMJ period. All four locations have operational CIMEL sunphotometers and their advantage being the adequately placed spatial distribution with Jaipur located around eastern edge of the Thar Desert. In the IGP, Gual Pahari is located closest to the dust-source region, followed by Kanpur, while Gandhi College is the farthest. The overall pattern of size distribution is similar across all four sites characterized by a bi-modal log-normal distribution with a prominent peak in coarse mode in the monthly mean plots 

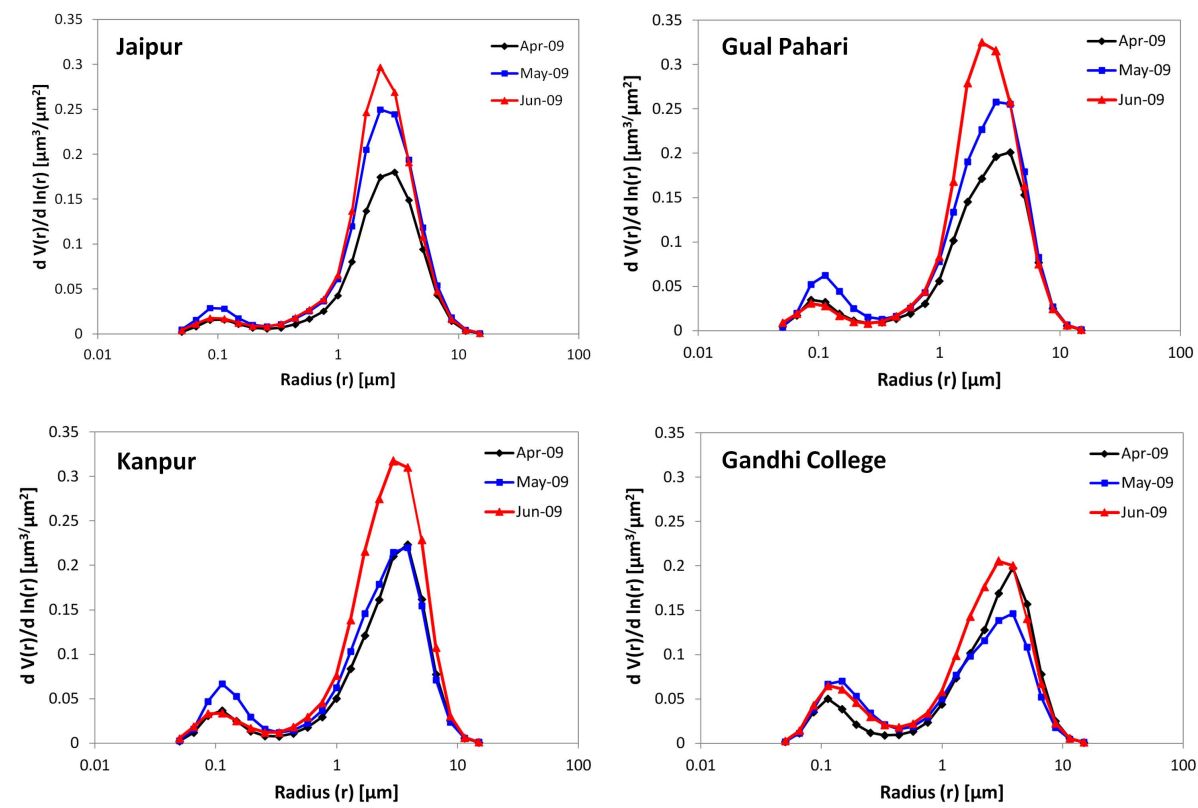

Fig. 7. Monthly mean aerosol size distribution from CIMEL sunphotometer over Jaipur, Gual Pahari (outskirts of Delhi), Kanpur and Gandhi College are shown for April (black), May (blue) and June (red) 2009.

suggesting the regional dust-dominated environment (Fig. 7). The fine-mode peak is small, with values in the range 0.02 $0.07 \mu \mathrm{m}^{3} / \mu \mathrm{m}^{2}$, centered around $0.11-0.14 \mu \mathrm{m}$, associated with the relatively lower anthropogenic aerosol content during pre-monsoon season. In general, greater influence of dust loading is observed in the coarse mode peak of May-June that is systematically higher than April over Jaipur, Gual Pahari and Kanpur. The log-normal aerosol size distribution shows mean values of $0.2-0.33 \mu \mathrm{m}^{3} / \mu \mathrm{m}^{2}$, centered around 2.2-2.9 $\mu \mathrm{m}$, radius corresponding to the dust-laden May-June period over Jaipur, Gual Pahari and Kanpur. On the other hand, Gandhi College does not exhibit a similar systematic change in size distribution from April to June. While there is an apparent peak in the coarse mode, the volume size distribution values ( 0.15 to $0.2 \mu \mathrm{m}^{3} / \mu \mathrm{m}^{2}$ ) are significantly smaller compared to the western regions. Overall, the greater influence of dust transport is evident based on the lower AE over Jaipur and Western IGP compared to higher AE value over Gandhi College during the pre-monsoon period (see Table 1 for more details).

A similar pattern of aerosol distribution was found across the foothill/slope regions. Figure 8 shows AOD plotted against the $\mathrm{AE}$ at western locations (top panel), while bottom panel shows the AOD vs. AE relationship over the three transect sites in Nepal in increasing order of elevation. The western foothill and slope locations - Chitkara and Shimla, are about $30 \mathrm{~km}$ apart but vary greatly in elevation and are characterized by a mixed aerosol type indicated by the AOD values distributed evenly across the AE $(0-1.4$ for Chitkara and $0-1.7$ for Shimla). The distribution of instantaneous measurements, as shown in Fig. 8, indicates a mix of fineand coarse-mode particulates associated with dust loading and anthropogenic pollution. Mean values of AOD (AE) over Chitkara and Shimla for the measurement period are $0.57 \pm 0.25(0.72 \pm 0.28)$ and $0.33 \pm 0.18(0.87 \pm 0.34)$, respectively. For the sake of comparison, AOD vs. AE relationship over Jaipur is also shown where dust loading is largest with more than $90 \%$ of aerosol retrievals associated with $\mathrm{AE}$ less than 0.5. In contrast, foothill/slope region in Nepal witnessed more fine-mode particles as clearly indicated by the majority of AOD measurements associated with AE greater than 1 (Fig. 8). Aerosol loading was significantly higher over the foothill location at Hetauda (AOD 0.75) and the middle mountain-valley location at Dhulikhel (AOD 0.73) compared to the remote elevated site of Langtang (AOD $\sim 0.35$ ) with $\mathrm{AE}>1$ at all three sites. It must be pointed out here that relatively fewer measurements were obtained at Langtang due to the shorter deployment time period. Recently, Dey and Di Girolamo (2010) also showed larger volume of fine-mode aerosols with higher spherical particulate contribution over the foothill region compared to that over the IGP during pre-monsoon season, based on MISR satellite retrievals. Overall comparison of mean AE (see Table 1), for the measurement period, over the foothill/slope regions in Northwestern India and Nepal indicates smaller contribution of coarse particles in Nepal (at all three locations) compared to the western Himalayan region, similar to the aerosol distribution in the west-east domain of IGP. 


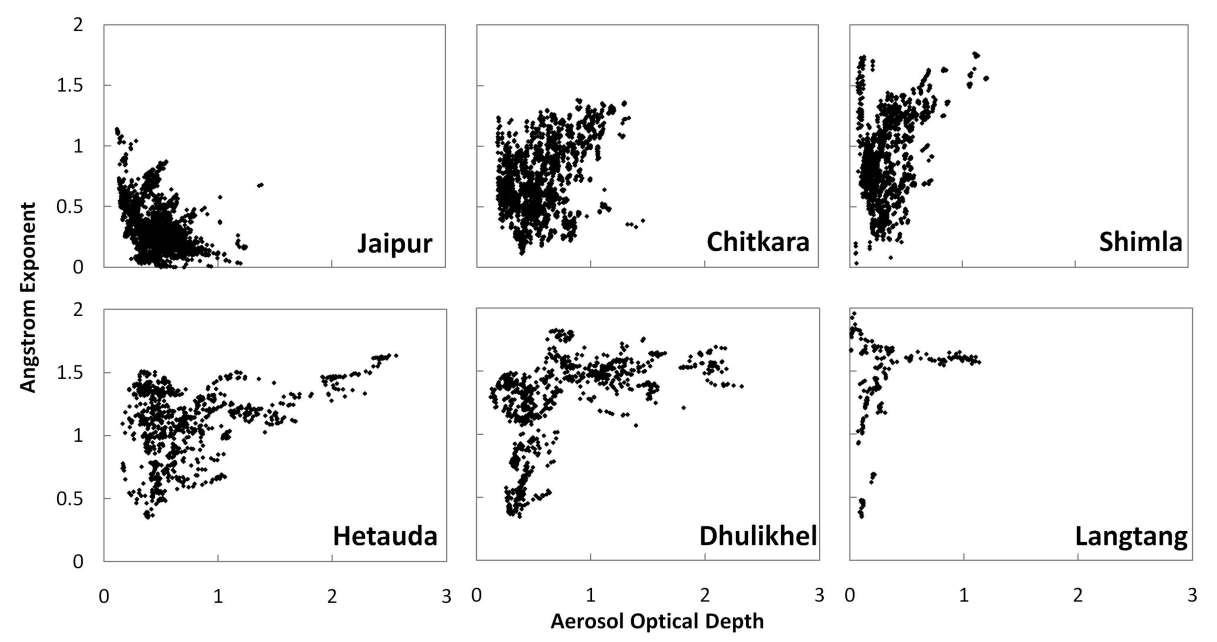

Fig. 8. Scatter plots between AOD and AE for the foothill and slope of the Western (top panel) and Eastern Himalayas (bottom panel) over Jaipur, Chitkara and Shimla in India, and over Hetauda, Dhulikhel, and Langtang, respectively. Data points shown are instantaneous retrievals during the 2009 pre-monsoon season.

\subsection{Diurnal variability}

Next, we also present diurnal patterns in aerosol loading over the closely-spaced AERONET sites in the complex terrain of Nepal transect in order to further investigate accumulation of aerosols from the foothill to elevated mountain slopes region of the Himalayas. Difference between all instantaneous column-integrated measurements, for a given day, from the respective daily mean is taken to represent the percent AOD departures, followed by averaging the departures in hourly intervals. This procedure is applied to the pre-monsoon dataset over the three locations namely, Hetauda, Dhulikhel and Langtang. The methodology for analyzing diurnal variability pattern in aerosol loading is similar to previous works by Smirnov et al. (2002) and allows to systematically study diurnal variability and helps in identifying patterns in aerosol loading on an hourly scale. Similar procedure was applied to water vapor and $\mathrm{AE}$ measurements from the sunphotometer data to see any indication of changes in moisture loading and particle size. Figure 9 shows the resulting diurnal patterns for $\mathrm{AOD}$ (red), $\mathrm{AE}$ (green) and water vapor (blue) for (a) Hetauda, (b) Dhulikhel, and (c) Langtang. A strong diurnal pattern in aerosol loading with a characteristic late afternoon peak generally between 15:00 and 17:00 LT, relative to the early morning low departures, is clearly observed at all sites. In terms of AOD departures, the difference between the lateafternoon high and early-morning low increases as a function of elevation with peak difference observed to be $13 \%, 16 \%$ and $75 \%$ at Hetauda (465 m a.s.1.), Dhulikhel (1500 m a.s.1.) and Langtang ( $3670 \mathrm{~m}$ a.s.l.). It is also noted that diurnal pattern in $\mathrm{AE}$ also indicate generally higher values during late afternoon at Hetauda and Dhulikhel suggesting reduced particle size (more fine-mode aerosol concentration lifted up) relative to early morning hours. However, at Langtang, even though the aerosol loading/concentration significantly increases, a significant diurnal pattern in $\mathrm{AE}$ is absent due to the abundance of fine-mode aerosols (AE > 1.2) since Langtang has minimal local influences, i.e. aerosols observed are mostly attributed to upslope transport. In addition, water vapor loading also exhibits similar diurnal pattern resembling that of AOD, with late-afternoon high departures compared to low values during early morning hours, consistent at all sites. Especially at Langtang, the diurnal variations and afternoon peak of AOD and water vapor departures are found to be strongly correlated. The noted patterns suggest strong boundary layer evolution leading to high aerosol concentrations during afternoon associated with enhanced convection and increased ventilation/upslope transport of pollutants in the higher levels of free troposphere, relative to low (or background) aerosol concentrations during the early morning stable environment. However, the diurnal variability patterns presented here are based on limited measurements made during the 2009 pre-monsoon season and therefore continuous column and in-situ measurements are required for improved understanding of regional aerosol diurnal characteristics.

Similar pattern of strong diurnal cycle, especially of maximum concentrations in fine particles $-\mathrm{BC}$ and $\mathrm{PM}_{1}$, was also observed at an even higher elevated site over Nepal Climate Observatory - Pyramid (NCO-P) at 5079 ma.s.l., $\sim 100 \mathrm{~km}$ east of Langtang, during pre-monsoon season from in-situ measurements (Marinoni et al., 2010). The characteristic afternoon peak was attributed to lifting of pollutants by thermal winds further suggesting accumulation and longer lifetime of pollutants in higher residual layer. Over other elevated mountain peaks/slopes of the Himalayas in India, diurnal observations have also indicated similar pattern in aerosol loading. For example, at Nainital (1970 m a.s.1.), in-situ and column-integrated measurements showed higher 
afternoon $\mathrm{BC}$ concentrations and AODs, respectively, relative to low morning values, strongly coupled with the local boundary layer dynamics (Beegum et al., 2008; Dumka et al., 2008). Interestingly, it was also shown that the enhancement in BC levels in afternoon at Nainital coincides with lower afternoon concentrations over IGP during premonsoon season (Beegum et al., 2008). Similarly, fine and total particle number concentrations measured at Mukteshwar ( $2000 \mathrm{~m}$ a.s.l.) showed broad afternoon peak relative to low morning-nighttime concentrations during pre-monsoon season with lower SSA compared to other seasons (Hyvarinen et al., 2009; Komppula et al., 2009). Thus, our observations of a distinct diurnal cycle, combined with other previous studies showing similar pattern, suggest that the increased ventilation/upslope transport of pollutants leading to the characteristic large afternoon aerosol loading peak is not only specific to mesoscale vertical transport, but in essence may well represent large-scale lifting of aerosols along the southern slopes of the extensive Himalayan range from west to east during pre-monsoon season. Furthermore, it can be speculated that the influx and accumulation of absorbing aerosols over the IGP and the subsequent large-scale upslope lifting is an efficient mechanism of vertical aerosol transport and deposition over the exposed snow and ice surface of the Himalayan cryosphere during pre-monsoon season and hence may cause accelerated snow melt - a topic under investigation by many (Flanner et al., 2007; Ming et al., 2008; Yasunari et al., 2009; Lau et al., 2010; Qian et al., 2011).

\subsubsection{Aerosol single scattering albedo}

In this section, we report SSA values obtained from AERONET sun photometers over northern India and Nepal. Table 2 and Fig. 10 show the mean spectral SSA variation at each location. Here, SSA values corresponding to $\mathrm{AOD}_{440 \mathrm{~nm}}>0.4$ are only considered in the analysis since the inversion-based AERONET SSA retrievals may be subject to greater uncertainty in low aerosol loading conditions. Amongst the most scattering aerosol type, SSA over Jaipur is systematically higher than other regions of IGP due to its proximity to the Thar Desert. The spectral shape clearly indicate dominance of dust with $\mathrm{SSA}_{440 \mathrm{~nm}}$ being the lowest (absorbing) to increasing values at longer wavelengths (scattering) $-\mathrm{SSA}_{440 \mathrm{~nm}}=0.88$ and $\mathrm{SSA}_{1020 \mathrm{~nm}}=0.96$. Compared to Jaipur, the spectral SSA at Gual Pahari and Kanpur also exhibit similar pattern, representing dust-dominated environment, but indicate the presence of fairly greater absorbing aerosol concentration as suggested by the lower values, especially in the $670 \mathrm{~nm}-1020 \mathrm{~nm}$ range. On the contrary, relatively flat spectrum is found at Gandhi College compared to the western locations, with lower SSA $(<0.9)$ at longer wavelengths, suggesting reduced dust loading and presence of greater absorbing aerosol concentration, in general, associated with local anthropogenic pollution.
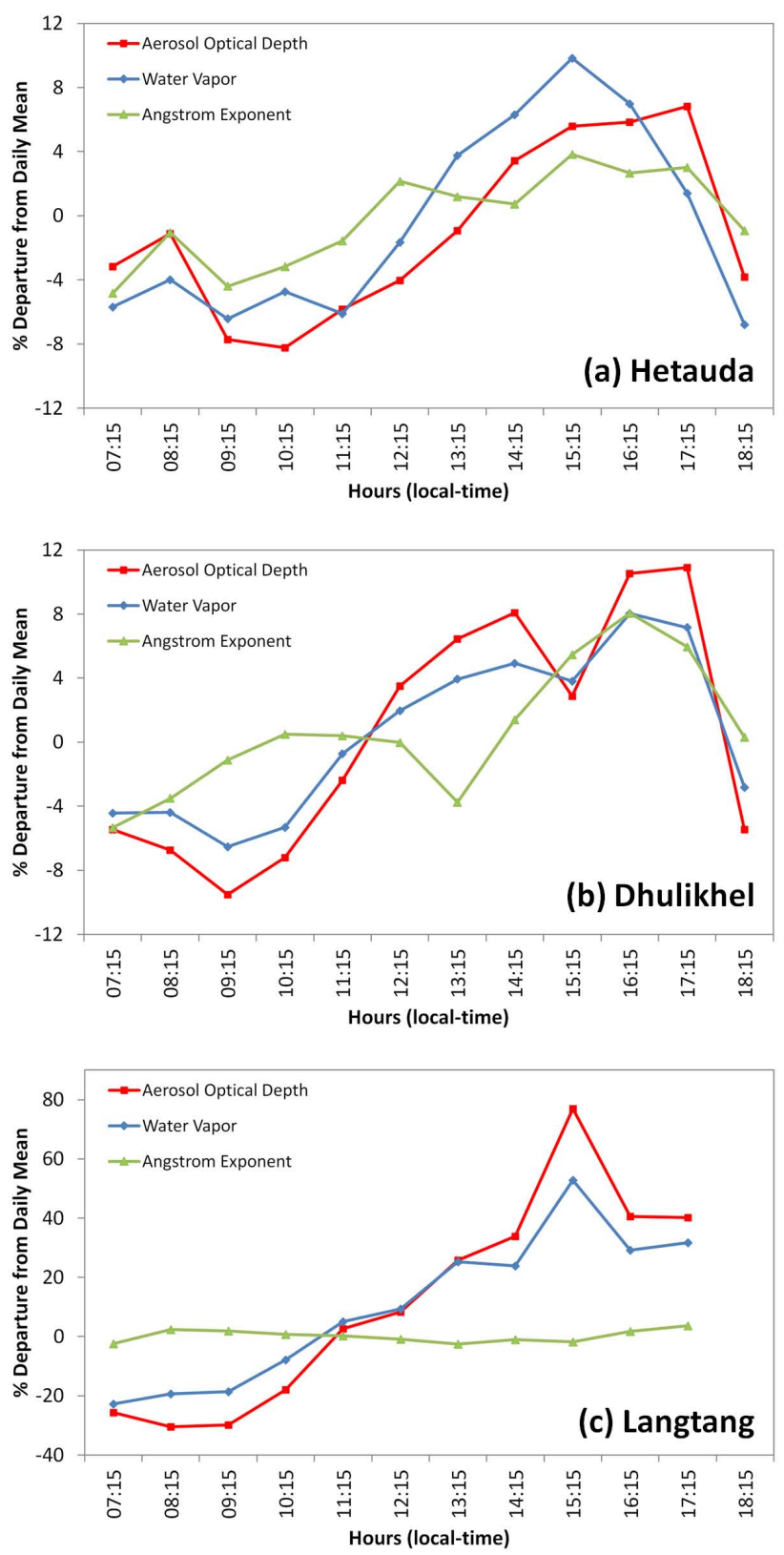

Fig. 9. Diurnal variability of column integrated aerosol loading (AOD), water vapor and Angstrom Exponent over three transect locations in Nepal (a) Hetauda (foothill), (b) Dhulikhel (slope-valley) and (c) Langtang (elevated site). Diurnal variability is calculated from CIMEL sunphotometer data and is represented by calculating hourly percentage departure of the three variables from their daily mean values. A characteristic afternoon peak in AOD and water vapor is observed at all sites associated with the enhanced convection and upslope transport of pollutants.

Over Nepal, SSA values from AERONET present an interesting pattern of absorbing aerosol distribution from the foothill to elevated sites within the transect. Firstly, the SSA over transect locations, i.e. from $465 \mathrm{~m}$ to $3670 \mathrm{~m}$ elevation, 
Table 2. Aerosol Single Scattering Albedo values obtained from our model calculations (indicated by *) and AERONET sunphotometer measurements (indicated by **), for the 2009 premonsoon period, over various measurement sites at near-Desert (Jaipur), Indo-Gangetic Plains (Gual Pahari, Kanpur, Gandhi College) and foothill/slope stations (Chitkara, Hetauda, Dhulikhel and Langtang).

\begin{tabular}{|c|c|c|c|c|c|c|c|c|c|}
\hline$\lambda(\mathrm{nm})$ & Jaipur* & Chitkara* & Jaipur** & Gual Pahari** & Kanpur** & Gandhi College** & Hetauda** & Dhulikhel** & Langtang** \\
\hline 397 & $0.85 \pm 0.022$ & $0.90 \pm 0.013$ & & & & & & & \\
\hline 441 & & & $0.88 \pm 0.023$ & $0.86 \pm 0.02$ & $0.87 \pm 0.019$ & $0.88 \pm 0.028$ & $0.86 \pm 0.02$ & $0.88 \pm 0.02$ & $0.89 \pm 0.03$ \\
\hline 467 & $0.88 \pm 0.019$ & $0.91 \pm 0.013$ & & & & & & & \\
\hline 546 & $0.91 \pm 0.018$ & $0.93 \pm 0.012$ & & & & & & & \\
\hline 642 & $0.93 \pm 0.014$ & $0.94 \pm 0.009$ & & & & & & & \\
\hline 676 & & & $0.93 \pm 0.023$ & $0.89 \pm 0.03$ & $0.91 \pm 0.028$ & $0.89 \pm 0.028$ & $0.87 \pm 0.02$ & $0.89 \pm 0.02$ & $0.86 \pm 0.02$ \\
\hline 869 & & & $0.95 \pm 0.019$ & $0.91 \pm 0.03$ & $0.93 \pm 0.03$ & $0.90 \pm 0.029$ & $0.88 \pm 0.02$ & $0.88 \pm 0.02$ & $0.85 \pm 0.02$ \\
\hline 1000 & $0.93 \pm 0.012$ & $0.92 \pm 0.007$ & & & & & & & \\
\hline 1020 & ' & & $0.96 \pm 0.016$ & $0.92 \pm 0.03$ & $0.93 \pm 0.03$ & $0.90 \pm 0.030$ & $0.89 \pm 0.02$ & $0.89 \pm 0.02$ & $0.84 \pm 0.02$ \\
\hline
\end{tabular}

is quite low ( $<0.9$ at each wavelength) and hence quite absorbing due to mixed state of anthropogenic pollution, longrange transport of dust (Carrico et al., 2003) and biomass burning smoke in the form of intense forest fires witnessed during the pre-monsoon period. The spectral shape of SSA over the foothill site (Hetauda) is quite similar to that of Gandhi College ( $\sim 190 \mathrm{~km} \mathrm{S-SW}$ of Hetauda) with slightly lower values at Hetauda. Similar spectral shape suggests the possibility of similar aerosol type with slightly more absorbing aerosols at Hetauda compared to Gandhi College. There also exists some influence of dust which can be inferred from the spectral SSA shape at Hetauda - most likely due to transported dust and/or disturbed soil associated with urban activities. Note that a partial coarse particulate influence over Hetauda was observed earlier in the AOD vs. AE relationship thus complementing the SSA variation. Compared to Hetauda, dust/coarse particle influence is found to weaken over Dhulikhel that shows a relatively flat spectrum suggesting a mix of local pollution aerosols from upslope transport as well as long-range transport of dust (Carrico et al., 2003; Shrestha et al., 2010). Unlike over Western IGP, SSA over Hetauda and Dhulikhel is generally lower at longer wavelengths $(670-1020 \mathrm{~nm})$ and less sensitive to variation in wavelength. Chemical composition analysis carried out by Shrestha et al. (2010) over Dhulikhel during the 2009 pre-monsoon period indicates organic carbon as a major fraction of the aerosol concentration with major sources of pollution in Kathmandu valley, in particular, and over the IGP, in general. Additionally, their chemical analysis found about $10 \%$ contribution from elemental carbon in the total aerosol composition suggesting presence of significant absorbing aerosol concentration thus implying overall low spectral SSA (greater absorption) as reported here by AERONET over Dhulikhel.

Quite different from the two locations in Nepal, as well as from IGP, is the SSA variation over the elevated site at Langtang where $\mathrm{SSA}_{440 \mathrm{~nm}}$ is 0.89 and drops to 0.84 at $1020 \mathrm{~nm}$. The reversed shape of the SSA spectrum thus suggests a mixed state of scattering water soluble and carbonaceous aerosols associated with the injection of polluted boundary layer as well as smoke from forest fires in the slopes. Insitu measurements at Langtang have previously showed increased concentrations of sulfate, nitrate and other scattering species that constitute a major fraction of the aerosol composition (Carrico et al., 2003). In addition, enhanced levels of carbonaceous aerosols during pre-monsoon season have also been found over Langtang (Carrico et al., 2003) and also at an even higher elevated site over Nepal Climate Observatory - Pyramid (NCO-P) at 5079 m a.s.l., $\sim 100 \mathrm{~km}$ east of Langtang, (Decesari et al., 2010; Marinoni et al., 2010; Marcq et al., 2010). Low SSA values $(<0.85$ at $670-700 \mathrm{~nm})$ were measured regularly at NCO-P in particular during episodes of regional pollution during pre-monsoon season (Marcq et al., 2010). In comparison, AERONET at Langtang also provides a considerably low value of 0.86 at $\sim 700 \mathrm{~nm}$ (Table 2) suggesting similar distribution of absorbing aerosols in the elevated Himalayas. Aforementioned studies including the analysis by Carrico et al. (2003) also found evidence of mineral dust in the aerosol load over elevated regions, which is not captured in the spectral SSA reported here at Langtang. The lack of dust influence as inferred from AERONET SSA (Fig. 10) as well as the previous observation of significantly low fraction of coarse particles in the AOD vs. AE relationship (with over $90 \%$ of aerosol retrievals corresponding to $\mathrm{AE}>1$, Fig. 8), may be attributed to the smaller sample size obtained for the period 24 April-10 May at Langtang. The dust transport activity usually peaks in May-June and therefore our short sampling period at Langtang, ending in early May, may not have captured the longrange transport of dust and therefore does not reflect seasonal mean aerosol characteristics. Overall, limited observations of spectral SSA during the 2009 pre-monsoon period suggest the presence of greater absorbing aerosol concentration (SSA $440-1020 \mathrm{~nm} \sim 0.85-0.9)$ over foothill/slope and remote elevated sites in Nepal compared to the IGP. 

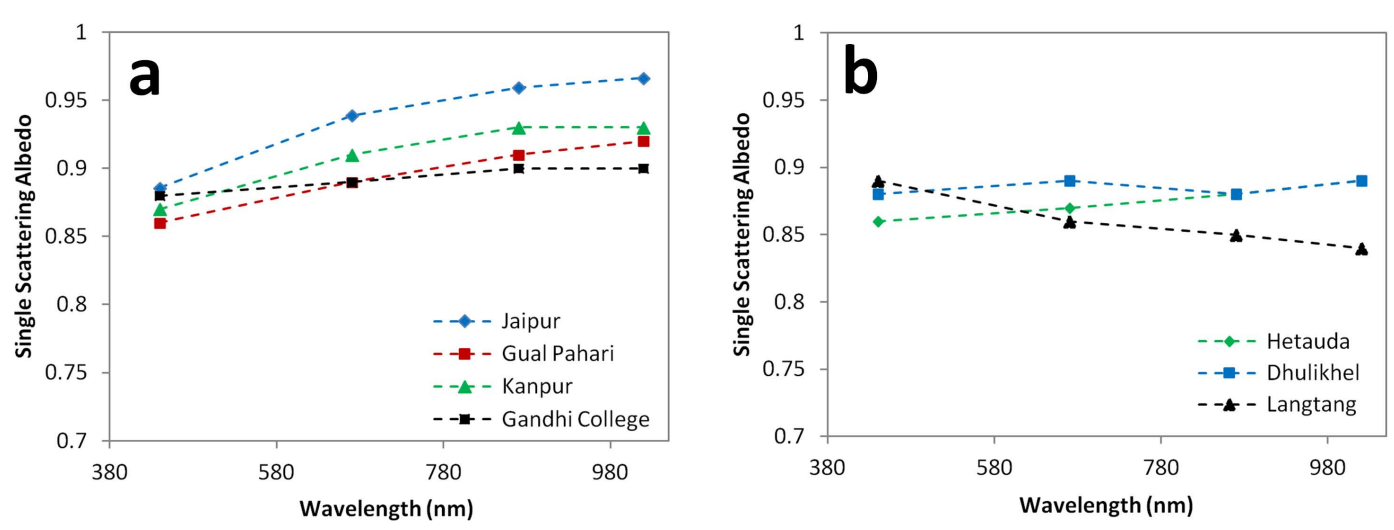

Fig. 10. SSA from AERONET sunphotometers at (a) Jaipur, Gual Pahari, Kanpur and Gandhi College in Northern India, and (b) at Hetauda, Dhulikhel and Langtang of Himalayan foothill/slope regions Nepal. The SSA from AERONET is retrieved at four wavelengths - $440 \mathrm{~nm}$, $670 \mathrm{~nm}, 870 \mathrm{~nm}$ and $1020 \mathrm{~nm}$. Values shown are mean SSA for the 2009 pre-monsoon measurement period. Other details including the standard deviation of SSA are given in Table 2 and information of measurement sites (coordinates, elevation) is given in Table 1.

\section{Direct aerosol radiative effect}

Surface flux measurements from pyranometer were subjected to cloud-screening as discussed previously in Sect. 2.1. The resulting flux data that fall within the successive AOD retrieval criteria are deemed cloud-less and selected for further analysis. Our study presented here benefits from greater cloud-free conditions during the dry pre-monsoon time frame, especially over Northwestern India where the monsoon rainfall arrives around June-end. Figure 11a shows the aerosol-induced reduction in irradiance over Jaipur given by the aerosol forcing efficiency (forcing per unit optical depth, $f_{\mathrm{e}, \mathrm{a}}$ ) from flux observations for April-May-June over the solar zenith angle (SZA) interval of $25^{\circ}-35^{\circ}$. The observed surface flux was characterized by running a 1dimensional radiative transfer model (Fu and Liou, 1993) and subsequently the attenuation in surface flux due to aerosol solar absorption was better understood with the cloud-free model.

The overall comparison between the observed (x-axis) and model simulated flux (y-axis) is shown in Supplement Fig. S4 for Jaipur at $25^{\circ}-35^{\circ} \mathrm{SZA}$ interval. The forcing efficiency is largely sensitive to aerosol solar absorption and responds significantly to the aerosol optical model. Inputs to the external mixture for Jaipur consisted of $60-65 \%$ dust, $30-35 \%$ water soluble and $4-5 \%$ soot components which yielded a close agreement between the modeled and observed flux as indicated by the rms and mean difference, i.e. 14.7 and $8.5 \mathrm{Wm}^{-2}$, respectively (Supplement Fig. S4). Similarly, the external mixture over Chitkara comprised 30-35\% dust, $65-70 \%$ water soluble and $2 \%$ soot and the comparison between observed and modeled flux is shown in Supplement Fig. S5. This tuning procedure is used to account for aerosol absorption by constraining the model with observed forcing efficiency as a means to achieve reasonable estimates of aerosol forcing for the region; this approach is similar to that previously applied over Kanpur (Gautam et al., 2010). The diurnal forcing efficiency ( $24 \mathrm{~h}$ average) calculated at an increment of each solar zenith angle is found to be $-52.5 \mathrm{Wm}^{-2} \mathrm{AOD}^{-1}$ and $-38 \mathrm{Wm}^{-2} \mathrm{AOD}^{-1}$ for Jaipur and Chitkara, respectively. The resulting clear-sky diurnal aerosol forcing (aerosol-laden minus aerosol-free flux) over Jaipur ranges from -5.5 to $-36.5 \mathrm{Wm}^{-2}$ and the mean surface forcing is found to be $-23.3 \mathrm{Wm}^{-2}$, suggesting cooling influence at surface. Over Chitkara, the clear-sky aerosol forcing ranges from -5.6 to $-39.6 \mathrm{Wm}^{-2}$, while the mean value is found to be $-19.6 \mathrm{Wm}^{-2}$. The SSA estimated from our model calculations are also presented here (see Table 2) and compared with that from AERONET. Supplement Fig. S4 shows close agreement in the SSA values and the spectral shape between model calculation and AERONET at Jaipur, for the measurement period, thus providing greater confidence in modeled surface fluxes and aerosol radiative forcing estimation as reported above.

\subsection{Uncertainty in aerosol radiative forcing estimation}

Uncertainties in the above aerosol shortwave radiative forcing (diurnally-averaged forcing at surface) estimates are also obtained from model sensitivity of various input parameters. Several variables factor into the overall uncertainty as listed in Table 3, as estimated from perturbing input variables in radiative forcing calculations with only one variable perturbed with others fixed. Table 3 lists the various sensitivity parameters namely, aerosol optical model, aerosol height, broadband surface albedo, AERONET water vapor retrieval uncertainty (Schmid et al., 2001) and AERONET AOD retrieval uncertainty. In the case of aerosol optical model, several dust models, available from the OPAC database (Hess et al., 1998) were used to obtain the sensitivity to surface fluxes with all other parameters fixed. The various dust models included 

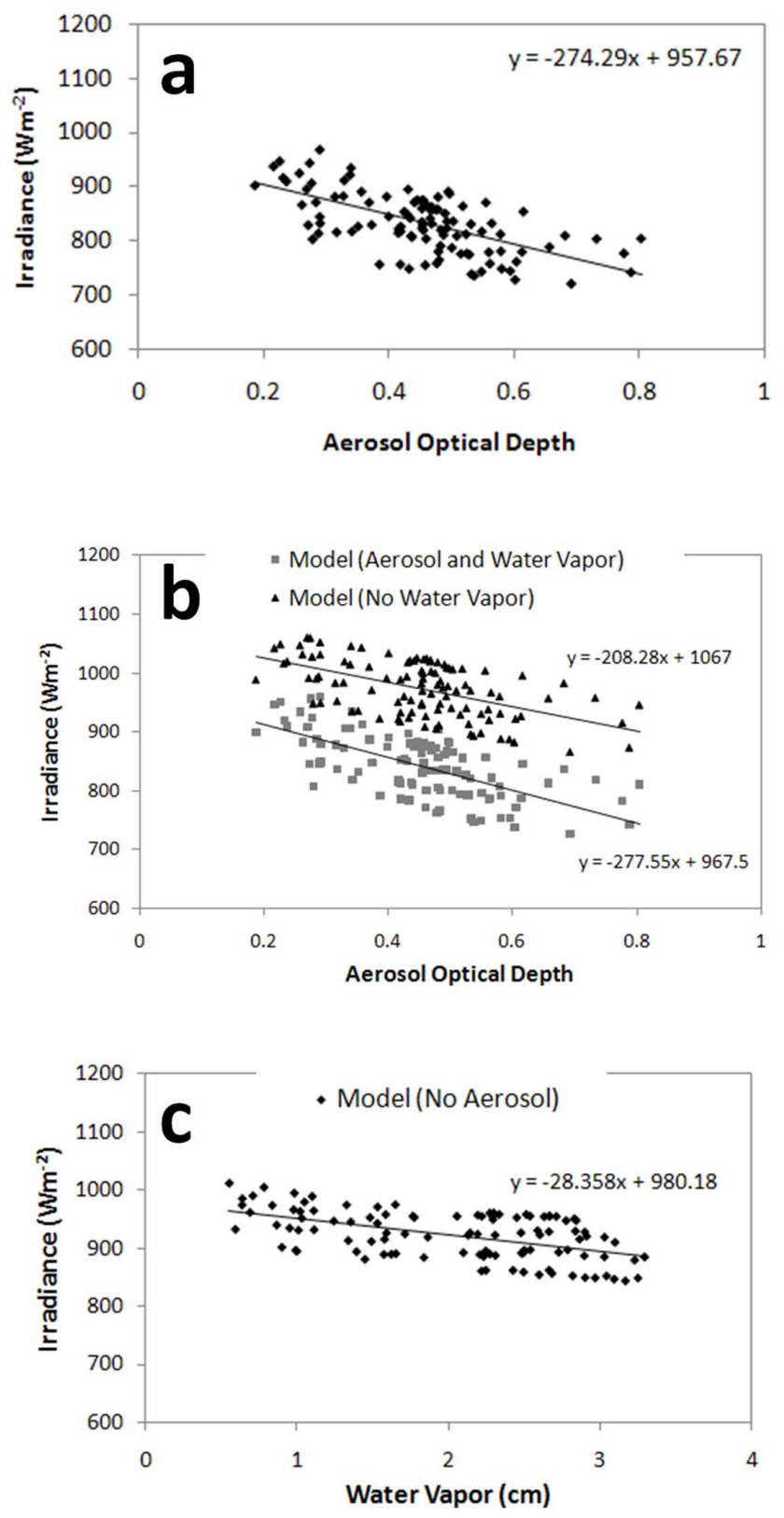

Fig. 11. (a) Instantaneous forcing efficiency $\left(F_{\mathrm{e}}\right)$ observed from pyranometer surface flux measurements over Jaipur at $25^{\circ}-35^{\circ}$ solar zenith angle, (b) model calculated $F_{\mathrm{e}}$ due to combined aerosol and water vapor radiative effect (black) and aerosol only with no water vapor input (grey), and (c) model calculated water vapor $F_{\mathrm{e}}$. Aerosol and water vapor inputs to model calculations are obtained from CIMEL sunphotometer measurements.

in the sensitivity correspond to different particle size distribution namely, dust $0.5 \mu \mathrm{m}$, dust $1.0 \mu \mathrm{m}$, dust accumulation mode and dust transported mode, see more details in Hess et al. (1998). Additionally, a small change $( \pm 1 \%)$ in the percent soot contribution to the total AOD was also introduced to see any significant variations in surface fluxes. The indi- vidual uncertainty to aerosol optical model is quite significant and was estimated to be $23 \%$ with dust size distribution most sensitive to surface fluxes. On the other hand, small change in modeled fluxes was obtained from variations in aerosol vertical distribution that yielded in less than $1 \%$ uncertainty. With respect to vertical profile inputs, we separate the aerosol and water vapor radiative forcing in model calculations (see more discussion in Sect. 6) by minimizing the relative humidity-dependency factor (aerosol humidification effect) and therefore the vertical distribution has small effect (with fixed column-integrated optical depth) on the diurnally-averaged surface forcing values $(<$ than $\pm 1 \%$ by perturbing a Gaussian aerosol profile peaking between 1 and $5 \mathrm{~km}$ ). Similarly, the sensitivity of broadband surface albedo to surface solar flux is quite small with a maximum value of $\pm 1.5 \%$ in the surface albedo range of $0.15-0.25$. Finally, the retrieval uncertainties in AERONET AOD and water vapor measurements resulted in $8 \%$ and $3 \%$ sensitivity to surface flux (Table 3 ). Thus, the overall uncertainty in estimation of diurnally averaged surface forcing, combining various aforementioned scenarios as listed in Table 3 (assuming individual uncertainties are not correlated), becomes $\pm 25 \%$ based on RMSE of the uncertainties arising from individual variables.

\subsection{Comparison of aerosol radiative effect with literature}

How do these aerosol forcing estimates compare with other regions in Northern India? Table 4 lists the various estimates of aerosol radiative forcing at surface and SSA, along with the location and measurement/method information, during pre-monsoon season over northern India (north of $20^{\circ} \mathrm{N}$ ) and Nepal. Based on previous studies, aerosol forcing values at other locations in northern India during pre-monsoon season suggest larger radiative effect regionally over the IGP and possibly higher absorbing aerosol content when compared to the values presented here over Northwestern India. For example, following a similar methodology (as presented here) over the urban/industrial Kanpur AERONET site in central IGP, the surface forcing efficiency and mean forcing values were estimated to be $-70 \mathrm{Wm}^{-2} \mathrm{AOD}^{-1}$ and $-44 \mathrm{Wm}^{-2}$ for the 2006-2007 pre-monsoon period (Gautam et al., 2010), indicating substantially higher aerosol solar absorption effect at surface (large cooling influence). Other estimates over Kanpur during pre-monsoon period also suggest large negative surface forcing value (greater than $-30 \mathrm{Wm}^{-2}$ ) when transported dust adds to the anthropogenic pollution (Dey and Tripathi, 2008). In terms of aerosol absorption, the SSA at $\sim 550 \mathrm{~nm}$ from our model calculations over Jaipur is estimated to be $0.91 \pm 0.018$ (from this study) compared to a lower value of $0.89 \pm 0.01$ at Kanpur, estimated from a similar methodology (Gautam et al., 2010), suggesting greater absorption in the IGP. For the sake of comparison of SSA within the NW arid region, only other estimate available is from Moorthy et al. (2007) at Jodhpur ( $300 \mathrm{~km} \mathrm{W-SW} \mathrm{of}$ 
Table 3. Uncertainty in radiative effect at surface from RTM calculations based on perturbations of several sensitivity variables including aerosol optical mode, aerosol height, broadband surface albedo and AERONET water vapor and AOD measurement uncertainties.

\begin{tabular}{llr}
\hline Sensitivity Variable & Perturbation Type/Range & $\begin{array}{r}\text { Uncertainty in Surface } \\
\text { Forcing Estimate }\end{array}$ \\
\hline & Dust $0.5 \mu \mathrm{m} /$ Dust $1.0 \mu \mathrm{m} /$ Mineral & $\pm 23 \%$ \\
Aerosol Optical Model & Accumulation mode/Mineral Transported mode/ & \\
& $\pm 1 \%$ change in soot & $\pm 1 \%$ \\
Aerosol Height & Gaussian Aerosol Profile within 1 and $5 \mathrm{~km}$ & $\pm 1.5 \%$ \\
Surface Albedo & $0.15-25$ & $\pm 3 \%$ \\
AERONET Water Vapor retrieval & $\pm 10 \%$ & $\pm 8 \%$ \\
AERONET AOD retrieval & $\pm 0.01 \pm 0.02$ & \\
\hline
\end{tabular}

Table 4. Aerosol radiative forcing estimates over Northern India and Nepal (north of $20^{\circ} \mathrm{N}$ ) during pre-monsoon season from this study and published literature.

\begin{tabular}{|c|c|c|c|c|c|c|}
\hline Site & Location & $\begin{array}{c}\text { Surface } \\
\text { Forcing } \\
\mathrm{Wm}^{-2}\end{array}$ & SSA & Period & Measurement/Method & Reference \\
\hline Jaipur & $26.90^{\circ} \mathrm{N}, 75.80^{\circ} \mathrm{E}, 450 \mathrm{~m}$ a.s. 1. & -23.3 & $0.91 \pm 0.018(\sim 550 \mathrm{~nm})$ & Apr-May-Jun & AERONET sunphotometer, pyranometer, RTM & This study \\
\hline Chitkara University & $30.86^{\circ} \mathrm{N}, 76.86^{\circ} \mathrm{E}, 520 \mathrm{~m}$ a.s. 1. & -19.6 & $0.93 \pm 0.012(\sim 550 \mathrm{~nm})$ & Apr-May-Jun & Microtops, pyranometer, RTM & This study \\
\hline Ahmedabad $(I)$ & $23.05^{\circ} \mathrm{N}, 72.55^{\circ} \mathrm{E}, 55 \mathrm{~m}$ a.s. 1 & -46 & - & Apr & Microtops, Aerosol In-Situ, RTM & Das and Jayaraman (2011) \\
\hline Ahmedabad (II) & $23.05^{\circ} \mathrm{N}, 72.55^{\circ} \mathrm{E}, 55 \mathrm{~m}$ a.s.l. & -44.7 & $0.69(550 \mathrm{~nm})$ & Mar-Apr-May & Microtops, BC In-Situ, RTM & Ramachandran and Kedia (2011) \\
\hline Udaipur & $24.58^{\circ} \mathrm{N}, 73.70^{\circ} \mathrm{E}, 500 \mathrm{~m}$ a.s.1. & -35 & - & Apr & Microtops, Aerosol In-Situ, RTM & Das and Jayaraman (2011) \\
\hline Mt. Abu & $24.65^{\circ} \mathrm{N}, 72.78^{\circ} \mathrm{E}, 1700 \mathrm{~m}$ a.s.l. & -31 & - & Apr & Microtops, Aerosol In-Situ, RTM & Das and Jayaraman (2011) \\
\hline Delhi (I) & $28.38^{\circ} \mathrm{N}, 77.17^{\circ} \mathrm{E}, 240 \mathrm{~m}$ a.s. 1. & -64 to -106 & $0.74-0.84(\sim 500 \mathrm{~nm})$ & Apr-May & PREDE sunphotometer, RTM & Pandithurai et al. (2008) \\
\hline Delhi (II) & $28.38^{\circ} \mathrm{N}, 77.17^{\circ} \mathrm{E}, 240 \mathrm{~m}$ a.s. 1. & -65 to -110 & $0.77-0.82(\sim 500 \mathrm{~nm})$ & Mar, May & Microtops, RTM & Singh et al. (2010) \\
\hline Kanpur (I) & $26.51^{\circ} \mathrm{N}, 80.23^{\circ} \mathrm{E}, 123 \mathrm{~m}$ a.s. 1. & -44 & $0.89 \pm 0.01(\sim 550 \mathrm{~nm})$ & Apr-May-Jun & AERONET sunphotometer, pyranometer, RTM & Gautam et al. (2010) \\
\hline Kanpur (II) & $26.51^{\circ} \mathrm{N}, 80.23^{\circ} \mathrm{E}, 123 \mathrm{~m}$ a.s.1. & -25 to -45 & $\sim 0.9(\sim 550 \mathrm{~nm})$ & Mar-Apr-May & AERONET sunphotometer, BC In-Situ, RTM & Dey and Tripathi (2008) \\
\hline Kanpur (III) & $26.51^{\circ} \mathrm{N}, 80.23^{\circ} \mathrm{E}, 123 \mathrm{~m}$ a.s. 1. & -26.1 to -31.7 & $0.92-0.94(675 \mathrm{~nm})$ & Apr-May-June & AERONET sunphotometer & Srivastava et al. (2011) \\
\hline Gandhi College & $25.87^{\circ} \mathrm{N}, 84.12^{\circ} \mathrm{E}, 60 \mathrm{~m}$ a.s. 1. & -29.7 to -31.9 & $0.88-0.92(675 \mathrm{~nm})$ & Apr-May-June & AERONET sunphotometer & Srivastava et al. (2011) \\
\hline Dibrugarh & $27.3^{\circ} \mathrm{N}, 94.6^{\circ} \mathrm{E}, 111 \mathrm{~m}$ a.s. 1. & -37.1 & $0.8(500 \mathrm{~nm})$ & Mar-May & Microtops sunphotometer, RTM & Pathak et al. (2010) \\
\hline $\begin{array}{l}\text { Nainital } \\
\text { Nepal Climate }\end{array}$ & $25.25^{\circ} \mathrm{N}, 81.58^{\circ} \mathrm{E}, 1970 \mathrm{~m}$ a.s. 1. & -26 to -53 & - & Mar-May & Microtops sunphotometer, RTM & Kumar et al. (2011) \\
\hline $\begin{array}{l}\text { Observatory- } \\
\text { Pyramid }\end{array}$ & $27.95^{\circ} \mathrm{N}, 86.82^{\circ}$ E, $5079 \mathrm{~m}$ a.s. 1. & -1.6 to -19 & $0.82-0.89(500 \mathrm{~nm})$ & Mar-May & AERONET sunphotometer, aerosol insitu, RTM & Marcq et al. (2010) \\
\hline
\end{tabular}

Jaipur, i.e. further closer to the Thar Desert) where SSA was inferred in the range of 0.88 to 0.94 (wavelength information is not clear). It is worth pointing out here that Jaipur is not truly representative of aerosols over Thar Desert since it is outside of the desert region and is an urban location. Therefore, it is reasonable to anticipate that the SSA value inside the desert/arid regions would be higher (lesser absorbing) than that reported here at Jaipur.

Outside of the NW region, near the western edge of the IGP, few studies over the urban Delhi environment have placed much higher estimates of surface forcing values for April-May-June period with lower SSA values (0.74-0.84 at $\sim 500 \mathrm{~nm})$ and attributed the large surface cooling and solar absorption to higher absorbing aerosol concentration (Pandithurai et al., 2008; Singh et al., 2010). Furthermore, larger surface cooling (and lower SSA), compared to our estimates in Northwestern India, has also been found over far Northeastern India $\left(-37 \mathrm{Wm}^{-2}\right.$ at Dibrugarh in the Brahmaputra river basin) where dust is not as abundant as compared to Northwestern India (and the western IGP), but does contribute to the seasonal peak values of AOD during pre- monsoon season (Pathak et al., 2010). Elevated slope-valley regions in Nepal are also influenced by significantly absorbing aerosols with lower dust fraction as seen in Fig. 10 as well as indicated by low SSA $(0.82-0.89$ at $500 \mathrm{~nm})$ estimates from the high elevation NCO-P site (Marcq et al., 2010). Thus, based on limited estimates of SSA from our model calculations and AERONET data presented in this paper as well as comparison of aerosol radiative forcing estimates over northern India, one may gather that transported dust in the IGP is more absorbing than the mineral dust originated over and around the Thar Desert in the NW corridor and causes spatial heterogeneity in aerosol radiative forcing in the west-east domain of Northern India.

\section{Relative contribution of water vapor radiative impact}

In this section, we investigate the radiative impact of the enhancement of WV with respect to the co-varying accumulation of aerosols over Northwestern India as observed in the sunphotometer data (discussed in Sect. 4.1). The goal of this 
section is to show the leading role of the coupled aerosoland moisture-laden airmass in influencing the overall observed aerosol radiative forcing impact. In conventional terminology, aerosol radiative forcing is the difference between aerosol-laden and aerosol-free flux in cloud-free atmosphere. The forcing thus signifies the absorption (or scattering) associated with the aerosol loading given other parameters are not subject to significant variations. However, in an environment where a strong association of aerosol loading with moisture influx co-occurs as observed here over Northwestern India (Jaipur and Chitkara), it may be crucial to study the two separately and to investigate the relative radiative impacts. Unlike the radiative impact of aerosol where surface cooling strongly depends on its SSA or absorbing nature, the water vapor radiative forcing (induced surface cooling) is simply a function of the water path abundance. Since water vapor has strong absorption bands in the near- and shortwave- IR wavelengths, it acts as an absorbing layer leading to reduction in downward solar flux. To further understand this, we will look at the shortwave WV radiative forcing (hereafter WRF), i.e. changes in flux with and without WV.

Over Northwestern (NW) India, we noted in the observations that the westerly airmass causing mineral dust influx is enriched with moisture as it moves over the northern Arabian Sea, thus resulting in a systematic and simultaneous increase in both column-integrated AOD and water vapor, during the course of the pre-monsoon period. From Fig. 6, aerosol and water vapor loading are found to be strongly correlated in Northwestern India (over Jaipur and Chitkara) with a large range observed for both AOD (from 0.2 to 1.5) and water vapor (from 0.4 to $4 \mathrm{~cm}$ ). The noted observations led us to infer that the regional aerosol radiative effect is convoluted with the water vapor forcing signal since it varies systematically. The water vapor radiative effect becomes more important because it is not constant and/or randomly distributed in the measurement time period. In this section, we discuss their relative/combined effects on net radiative effect in a coupled aerosol-water vapor airmass perspective.

First, we show the instantaneous pyranometer observations indicating the observed forcing efficiency $\left(F_{\mathrm{e}}\right)$ to be $\sim-274 \mathrm{Wm}^{-2-1} \mathrm{AOD}$ at $25^{\circ}-35^{\circ}$ solar zenith angle at Jaipur (Fig. 11a). This observed $F_{\mathrm{e}}$ is associated with the regional aerosol solar absorption; however, since the aerosol and water vapor radiative effects are convoluted in the data, we attempt to separate their relative impacts as opposed to the net observed aerosol-water vapor effect.

The relative impact assessment is carried out by turning on and off the observed aerosol and water vapor inputs in the RTM calculations, with all other variables fixed, and investigate the corresponding reduction (solar absorption) in downward solar flux. We previously noted in the paper that since the relative humidity is generally less than $50 \%$ during the dust-dominant dry pre-monsoon season, we therefore do not include aerosol humidification effect by turning off the RH dependency factor in the RTM, and thus focus only on the airmass effect driving the enhanced aerosol loading and moisture influx. Aerosol optical model (external mixture of dust, water soluble and soot components) inputs were previously discussed in Sect. 5 and are fixed for all computation cases.

We analyze three scenarios as follows:

\section{COMBINED AEROSOL AND WATER VAPOR (both aerosol and water vapor $\mathrm{ON}$ ),}

\section{AEROSOL ONLY (no water vapor input),}

\section{WATER VAPOR ONLY (no aerosol input).}

The COMBINED aerosol and water vapor run yields a $F_{\mathrm{e}}$ of $\sim-277 \mathrm{Wm}^{-2} \mathrm{AOD}^{-1}$ (in close agreement with observed $F_{\mathrm{e}}$ as discussed previously) associated with aerosol and water vapor absorption at Jaipur (Fig. 11b). In the case of AEROSOL only with no water vapor input, the $F_{\mathrm{e}}$ is estimated to be about $-208 \mathrm{Wm}^{-2} \mathrm{AOD}^{-1}$, largely associated with absorption from mineral dust and soot components, and is a significant fraction $(\sim 75 \%)$ of the combined $F_{\mathrm{e}}$ (Fig. 11b). Whereas, the WATER VAPOR $F_{\mathrm{e}}$ (as a function of water vapor) due to absorption of solar radiation by water vapor only is $\sim-28.3 \mathrm{Wm}^{-2} \mathrm{~cm}^{-1}$ at Jaipur (Fig. 11c) and is an order of magnitude smaller compared to the aerosol absorption effect, but is certainly a nonnegligible fraction $(\sim 10 \%)$ of the observed surface $F_{\mathrm{e}}$. In addition to the instantaneous forcing, diurnally averaged $F_{\mathrm{e}}$ also suggests $\sim 8 \%$ contribution from water vapor to the combined $F_{\mathrm{e}}$ (Fig. 12a). Similarly over Chitkara, the instantaneous slope or the efficiency for WRF is estimated to be $-25.6 \mathrm{Wm}^{-2} \mathrm{~cm}^{-1}$, in comparison to the observed instantaneous of $-212 \mathrm{Wm}^{-2} \mathrm{AOD}^{-1}$ (as shown in Supplement Fig. S6). This suggests a significant radiative impact of WV in the reduction of surface flux due to the strong absorption bands in the near- and shortwave- infrared spectrum. The diurnal WRF for Jaipur and Chitkara are estimated to be $-9.18 \pm 3.5 \mathrm{Wm}^{-2}$ and $-7.96 \pm 3 \mathrm{Wm}^{-2}$, respectively. Additionally, the radiative effects from the two independent variables i.e., aerosol radiative forcing only without any $\mathrm{RH}$ dependency, is compared with the WRF. It is found that aerosol and water vapor radiative forcing are strongly correlated over the two locations; Fig. 13 shows strong association in the diurnal aerosol and water vapor radiative forcing $\left(r^{2}=0.69\right.$ at Jaipur and $r^{2}=0.83$ at Chitkara) during the measurement period. Thus, we clearly see the amplification of aerosol absorption leading to enhanced surface forcing (cooling) due to water vapor radiative effect which is associated with the systematically co-varying aerosol and water vapor over Northwestern India. It is also noted that the modeled net $F_{\mathrm{e}}$ is not a linear combination of the respective aerosol and water vapor $F_{\mathrm{e}}$ which is an indication of the enhanced solar absorption especially at higher values of AOD and water vapor. 

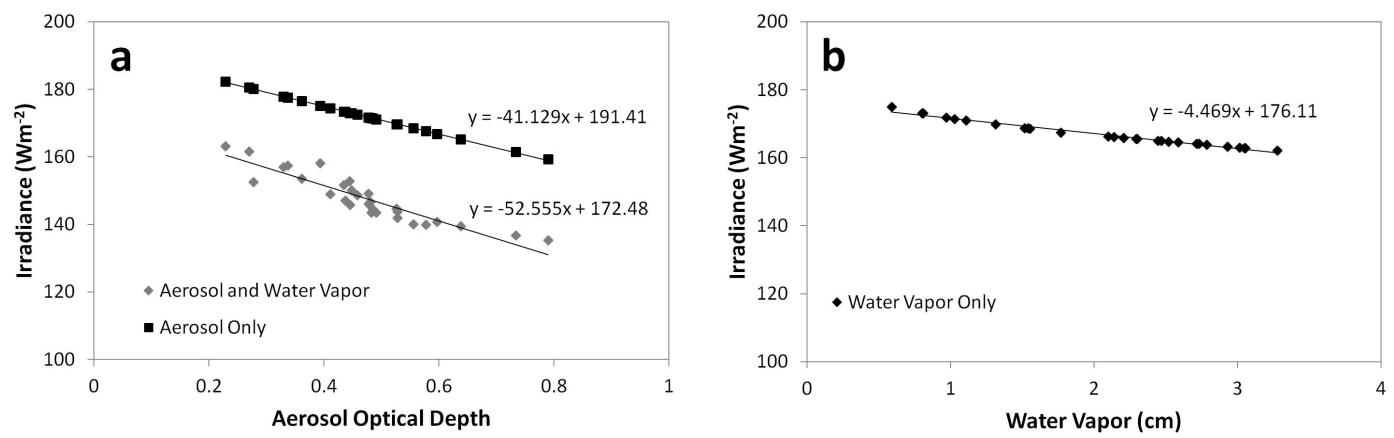

Fig. 12. Diurnally averaged forcing efficiency $\left(F_{\mathrm{e}}\right)$ at Jaipur obtained from model calculations for (a) combined aerosol and water vapor (grey) and aerosol only (black); (b) water vapor only with no aerosol input.
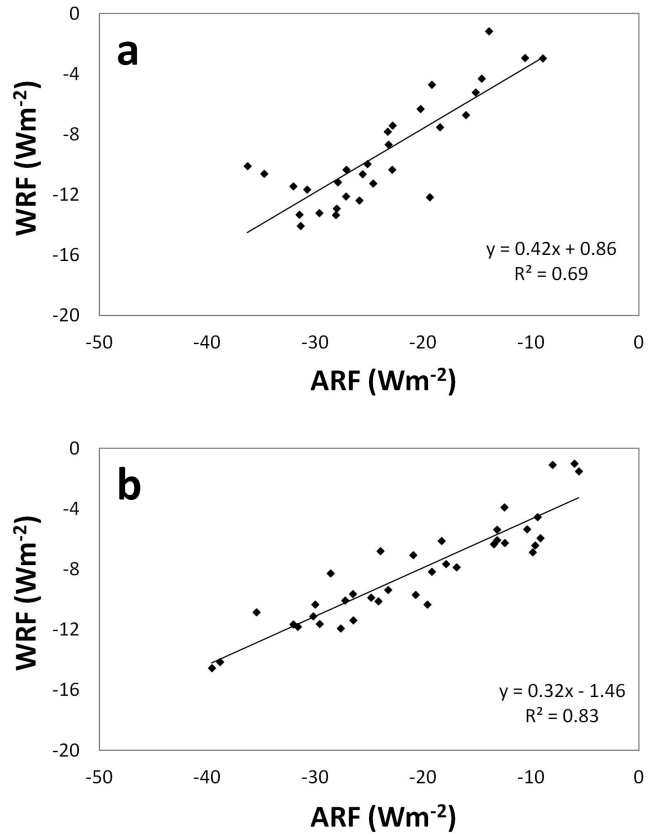

Fig. 13. Relationship between diurnal aerosol (ARF, x-axis) and water vapor (WRF, y-axis) radiative forcing over (a) Jaipur and (b) Chitkara, indicating moderate-strong association between the two forcings in Northwestern India.

We also found indication of the relative impact of water vapor radiative effect in the co-located pyranometersunphotometer data over Jaipur. To determine the water vapor effect, solar flux data were grouped based on low and high water vapor conditions given the aerosol loading was small and representative of the background AOD. First, the solar flux data were only selected corresponding to low AODs $(<0.3)$ and were further separated in low $(<1 \mathrm{~cm})$ and high $(>2.5 \mathrm{~cm})$ water vapor. Thus, two groups were formed and the corresponding fluxes were averaged, as shown in Supplement Fig. S7. Blue bars represent mean solar flux for the low AOD $(0.25 \pm 0.03)$ and low water vapor
$(0.78 \pm 0.16 \mathrm{~cm})$ group; and red bars correspond to the low AOD $(0.27 \pm 0.01)$ and higher water vapor $(2.73 \pm 0.07 \mathrm{~cm})$ group. The irradiance values (y-axis) indicate the instantaneous surface flux of $915 \pm 37 \mathrm{Wm}^{-2}$ and $843 \pm 34 \mathrm{Wm}^{-2}$ corresponding to low and high water vapor observations (first set of bars on extreme left of the x-axis), with similar background aerosol loading conditions at $25^{\circ}-5^{\circ}$ solar zenith angle over Jaipur, suggesting enhanced absorption associated with higher water vapor. Similarly, corresponding to the two groups, model calculations show a comparable difference in the surface fluxes between low and high water vapor conditions with both aerosol and water vapor inputs turned on in RTM calculations as indicated by the Aerosol and Water Vapor label on the X-axis of Supplement Fig. S7. Further, separating the impacts of water vapor (no aerosol) and aerosol (no water vapor) solar absorption clearly shows the large difference in fluxes associated with the water vapor radiative effect compared to the aerosol (only)-induced fluxes. It is to be noted that since aerosol and water vapor loading cooccurs, the sample size is limited with relatively few observations in the aforementioned groups. However, the detailed model calculations (instantaneous and diurnal) of separating aerosol and water vapor radiative effect and their combined role (seasonal progression of aerosol loading and moisture influx) in enhancing the overall net radiative impact, as well as indication of the enhancement in instantaneous observations, suggest that the two exert forcing in tandem leading to enhanced solar absorption/surface cooling.

\section{Conclusions}

Recent climate model-based studies have underscored the role of absorbing aerosols over South Asia in impacting the evolution and long-term variability of the summer monsoon rainfall (Ramanathan et al., 2005; Lau et al., 2006; Meehl et al., 2008) as well as cryospheric reservoirs of the HimalayasTibetan Plateau (Lau et al., 2010; Qian et al., 2011). This paper presents results from the RAJO-MEGHA field campaign related to aerosol and broadband surface flux measurements 
over Northern India and Nepal during the 2009 pre-monsoon season (April-June) to further understand regional aerosol distribution and radiative effects. Along with the existing sunphotometers as part of AERONET, aerosol and flux measurements were conducted in the vicinity of the dust-source region of Thar Desert, the IGP and foothill/slopes of the Himalayas, i.e. in the zonal, latitudinal and vertical domain of the Gangetic-Himalayan region. Sunphotometry over the nearly 3-month period captured the spatial distribution of aerosol loading and its optical properties over the westeast and north-south transects of the aerosol-laden valleytype setting of the IGP and of the foothill/elevated mountain slopes upto $3670 \mathrm{~m}$ a.s.l.. The progressive buildup of aerosol loading during the course of the pre-monsoon period was observed in the enhancement of AOD in the vicinity of the Thar Desert, over the IGP and as far as the elevated slopes associated with the predominately westerly airmass. Particularly over Northwestern India and Western IGP, the impact of large influx of mineral dust was observed resulting in characteristic increase in AOD, reduction in AE and strengthening of coarse mode in the volume size distribution. A prevailing westerly airmass is identified in largely governing the moisture influx and dust loading over Northwestern India and Western IGP, resulting in a steady and systematic increase of enhanced water vapor and AOD. Enhancement of water vapor and aerosol loading is observed over Northwestern India with a twofold increase from April to May and a strengthened relationship between the two is found to be associated with the prevalent westerly airmass as indicated by the boundary layer flow and daily airmass trajectory simulations.

On the contrary, due to the lack of a prevailing airmass associated with a typical pre-monsoonal cyclonic flow over Northeastern India, dust transport significantly weakens over the eastern parts of IGP and elevated sites along the southern slopes of the Himalayas in Nepal (east of $85^{\circ} \mathrm{E}$ ). Overall, Northwestern India and Western IGP is associated with greater dust transport compared to eastern IGP and Nepal as suggested by aerosol optical properties including size distribution, AE and spectral SSA. The SSA over Jaipur is estimated to be $0.91 \pm 0.018$ at $\sim 550 \mathrm{~nm}$, with our model calculations in close agreement compared to AERONETretrieved spectral SSA, and the spectral SSA is found to be higher (less absorbing aerosol) than other regions in the IGP. Over the eastern IGP (Gandhi College) and foothill/elevated slope regions in Nepal, fine-mode particles constitute bulk of the regional aerosol loading and the spectral SSA from AERONET suggests the presence of a strongly absorbing haze (SSA $\sim 0.85-0.9$ at $440-1020 \mathrm{~nm}$ ) associated with a mix of upslope transport of pollutants from Kathmandu valley (perhaps transported pollution from IGP as well) and biomass burning smoke aerosols (as a result of intense forest fires). Additionally, closely-spaced observations in the Nepal transect show a distinct diurnal pattern of a characteristic large afternoon aerosol and water vapor loading peak (relative to low values during early morning hours) from the foothill (Hetauda) to elevated mountain slopes (Langtang), associated with increased ventilation/upslope transport of pollutants and boundary layer dynamics. Together with similar diurnal variability observed over few other elevated locations in the Himalayas (Dumka et al., 2008; Beegum et al., 2008; Hyvarinen et al., 2008; Kompula et al., 2008; Marinoni et al., 2010), it appears that the broad afternoon aerosol loading peak is not specific to mesoscale vertical transport, but in essence may well represent large-scale lifting of aerosols along the southern slopes of the extensive $\mathrm{Hi}$ malayan range from west to east during pre-monsoon season. Furthermore, it can be speculated that the influx and accumulation of absorbing aerosols over the IGP and the subsequent large-scale upslope lifting is an efficient mechanism of vertical aerosol transport and deposition over the exposed snow and ice surface of the Himalayan cryosphere during pre-monsoon season and hence cause accelerated snow melt - a topic under investigation by many (Flanner et al., 2007; Ming et al., 2008; Yasunari et al., 2010; Lau et al., 2010; Qian et al, 2011).

In terms of direct aerosol radiative effect, shortwave flux observations and RTM calculations at surface were used to derive the aerosol radiative forcing efficiency, estimated to be -50 and $-38 \mathrm{Wm}^{-2}$ per unit optical depth over the source region of Northwestern India, with the diurnal mean reduction in surface fluxes found to be comparable within the region, -23 and $-19 \mathrm{Wm}^{-2}$, i.e. in the vicinity of Thar Desert and mountain slope, respectively. Based on limited radiometric observations of aerosol optical properties (optical depth, volume size distribution, SSA) and flux measurements during April-June 2009, and comparison of our estimates of aerosol radiative effects over northern India with published literature, it appears that transported dust in the IGP is more absorbing than the mineral dust originated over and around the Thar Desert and causes spatial heterogeneity in aerosol radiative forcing in the west-east domain of Northern India. Clearly, more in situ measurements are required to quantify chemical composition of the complex pre-monsoon aerosol loading in order to better understand the impact of absorbing aerosols, over the Gangetic-Himalayan region, in modulating the summer monsoon rainfall via radiative-dynamical interactions. Finally, the role of the enhancement of water vapor over Northwestern India is investigated in terms of its net effect on the aerosol radiative forcing. Relative contributions of radiative impacts of aerosol and water vapor absorption are assessed, focusing on the coupled airmass effect (and by isolating aerosol humidification effect), to determine the net surface forcing. Detailed model calculations (instantaneous and diurnal) of separating aerosol and water vapor radiative effect (and their combined role) show an overall enhancement of the net radiative impact and further suggest that the two exert forcing in tandem leading to enhanced solar absorption/surface cooling over Northerwestern India, associated with seasonal progression of aerosol loading and moisture influx.. 


\section{Supplement material related to this article is available online at: http://www.atmos-chem-phys.net/11/12841/2011/ acp-11-12841-2011-supplement.pdf.}

Acknowledgements. This work is supported by grant from the NASA Radiation Sciences Program, managed by Hal B. Maring. We are grateful to Ravi P. Singh (Sharda University), Varinder Kanwar (Chitkara University), Sunita Verma (BIT-Jaipur), Panna Thapa (Kathmandu University), Ana Barros (Duke University), Prabhakar Shrestha (Duke University) and Ramesh Singh (Chapman University) for providing invaluable assistance related to logistics and deployment, and useful discussions throughout the campaign. We also thank several collaborators and students from various Indian and Nepalese institutions for helping with operations and maintenance of the instruments. Gordon Labow, Charles Ichoku and Vanderlei Martins are sincerely acknowledged for providing us with 4 Microtops units that were used in northern India and Nepal. Dimitris Kaskaoutis and Sheng-Hsiang Wang also provided helpful comments on an earlier draft. The authors gratefully acknowledge the efforts made by the AERONET team/site PIs and operators (including at Gual Pahari, Kanpur and Gandhi College) and SMARTLabs team for making all the data available online. The airmass trajectories are computed from NOAA's HYSPLIT tool using the GDAS meteorological fields. Anonymous reviewers are thanked for constructive comments that helped improve an earlier version of the manuscript.

Edited by: Q. Fu

\section{References}

Beegum, S. N., Moorthy, K. K., Nair, V. S., Babu, S. S., Satheesh, S. K., Vinoj, V., Reddy, R. R., Gopal, K. R., Badarinath, K. V. S., Niranjan, K., Pandey, S. K., Behera, M., Jeyaram, A., Bhuyan, P. K., Gogoi, M. M., Singh, S., Pant, P., Dumka, U. C., Kant, Y., Kuniyal, J. C., and Singh D.: Characteristics of Spectral Aerosol Optical Depths over India during ICARB, J. Earth Syst. Sci., 117, 303-313, 2008.

Bhattacharjee, P. S., Prasad, A. K., Kafatos, M., and Singh, R. P.: Influence of a dust storm on carbon monoxide and water vapor over the Indo-Gangetic Plains, J. Geophys. Res., 112, D18203, doi:10.1029/2007JD008469, 2007.

Bollasina, M., Nigam, S., and Lau, K.-M.: Absorbing aerosols and summer monsoon evolution over South Asia: An observational portrayal, J. Clim., 21, 3221-3239, 2008.

Bonasoni, P., Laj, P., Marinoni, A., Sprenger, M., Angelini, F., Arduini, J., Bonafè, U., Calzolari, F., Colombo, T., Decesari, S., Di Biagio, C., di Sarra, A. G., Evangelisti, F., Duchi, R., Facchini, MC., Fuzzi, S., Gobbi, G. P., Maione, M., Panday, A., Roccato, F., Sellegri, K., Venzac, H., Verza, GP., Villani, P., Vuillermoz, E., and Cristofanelli, P.: Atmospheric Brown Clouds in the Himalayas: first two years of continuous observations at the Nepal Climate Observatory-Pyramid (5079 m), Atmos. Chem. Phys., 10, 7515-7531, doi:10.5194/acp-10-7515-2010, 2010.
Carrico, C. M., Bergin, M. H., Shrestha, A. B., Dibb, J. E., Gomes, L., and Harris J. M.: The importance of carbon and mineral dust to seasonal aerosol properties in the Nepal Himalaya, Atmos. Environ., 37, 2811-2824, 2003.

Collier, J. C. and Zhang, G. J.: Aerosol direct forcing of the summer Indian monsoon as simulated by the NCAR CAM3, Clim. Dyn., 32, 313-332, 2009.

Deepshikha, S., Satheesh, S. K., and Srinivasan, J.: Dust aerosols over India and adjacent continents retrieved using METEOSAT infrared radiance Part I: sources and regional distribution, Ann. Geophys., 24, 37-61, doi:10.5194/angeo-24-37-2006, 2006.

Das, S. K. and Jayaraman, A.: Role of black carbon in aerosol properties and radiative forcing over Western India during premonsoon period, Atmos. Res., 102, 320-334, doi:10.1016/j.atmosres.2011.08.003, 2011.

Dey, S., Tripathi, S. N., Singh, R. P., and Holben, B. N.: Influence of dust storms on the aerosol optical properties over the Indo-Gangetic basin, J. Geophys. Res., 109, D20211, doi:10.1029/2004JD004924, 2004.

Dey, S. and Tripathi, S. N.: Aerosol direct radiative effects over Kanpur in the Indo-Gangetic basin, northern India: Long-term (2001-2005) observations and implications to regional climate, J. Geophys. Res., 113, D04212, doi:10.1029/2007JD009029, 2008.

Dey, S., and Di Girolamo, L.: A climatology of aerosol optical and microphysical properties over the Indian subcontinent from $9 \mathrm{yr}$ (2000-2008) of Multiangle Imaging Spectroradiometer (MISR) data, J. Geophys. Res., 115, D15204, doi:10.1029/2009JD013395, 2010.

Dubovik, O., Sinyuk, A., Lapyonok, T., Holben, B. N., Mishchenko,M., Yang, P., Eck, T. F., Volten, H., Munoz, O., Veihelmann, B., van der Zande, W. J., Leon, J.-F., Sorokin, M., and Slutsker, I.: The application of spheroid models to account for aerosol particle non-sphericity in remote sensing of desert dust, J. Geophys. Res., 111, D11208, doi:10.1029/2005JD006619, 2006.

Dumka, U. C., Krishna Moorthy, K., Satheesh, S. K., Ram Sagar, Pant, P.: Short-Period Modulations in Aerosol Optical Depths over the Central Himalayas: Role of Mesoscale Processes, J. Appl. Meteor. Climatol., 47, 1467-1475, doi:10.1175/2007JAMC1638.1, 2008.

Dumka, U. C., Moorthy, K. K., Kumar, R., Hegde, P., Sagar, R., Pant, P., Singh, N., and Babu, S. S.: Characteristics of aerosol black carbon mass concentration over a high altitude location in the Central Himalayas from multi-year measurements, Atmos. Res., 96, 510-521, doi:10.1016/j.atmosres.2009.12.010, 2010.

Eck, T. F., Holben, B. N., Reid, J. S., Dubovik, O., Smirnov, A., O'Neill, N. T., Slutsker, I., and Kinne, S.: Wavelength dependence of the optical depth of biomass burning, urban, and desert dust aerosols, J. Geophys. Res., 104, 31333-31349, doi:10.1029/1999JD900923, 1999.

Eck, T. F., Holben, B. N., Sinyuk, A., Pinker, R. T., Goloub, P., Chen, H., Chatenet, B., Li, Z., Singh, R. P., Tripathi, S. N., Reid, J. S., Giles, D. M., Dubovik, O., O’Neill, N. T., Smirnov, A., Wang, P., and Xia, X.: Climatological aspects of the optical properties of fine/coarse mode aerosol mixtures, J. Geophys. Res., 115, D19205, doi:10.1029/2010JD014002, 2010.

Flanner, M. G., Zender, C. S., Randerson, J. T., and Rasch P. J.: Present-day climate forcing and response from black carbon in snow, J. Geophys. Res., 112, D11202, 
doi:10.1029/2006JD008003, 2007.

$\mathrm{Fu}, \mathrm{Q}$. and Liou, K. N.: Parameterization of the radiative properties of cirrus clouds, J. Atmos. Sci., 50, 2008-2025, 1993.

Gautam R., Liu, Z., Singh, R. P., and Hsu, N. C.: Two contrasting dust-dominant periods over India observed from MODIS and CALIPSO data, Geophys. Res. Lett., 36, L06813, doi:10.1029/2008GL036967, 2009a.

Gautam R., Hsu, N. C., Lau, K.-M., Tsay, S.-C., and Kafatos, M.: Enhanced pre-monsoon warming over the Himalayan-Gangetic region from 1979 to 2007, Geophys. Res. Lett., 36, L07704, doi:10.1029/2009GL037641, 2009b.

Gautam, R., Hsu, N. C., Lau, K.-M., and Kafatos, M.: Aerosol and rainfall variability over the Indian monsoon region: distributions, trends and coupling, Ann. Geophys., 27, 3691-3703, doi:10.5194/angeo-27-3691-2009, 2009.

Gautam, R., Hsu, N. C., and Lau, K.-M.: Premonsoon aerosol characterization and radiative effects over the Indo-Gangetic Plains: Implications for regional climate warming, J. Geophys. Res., 115, D17208, doi:10.1029/2010JD013819, 2010.

Giles, D. M., Holben, B. N., Tripathi, S. N., Eck, T. F., Newcomb, W. W., Slutsker, I., Dickerson, R. R., Thompson, A. M., Wang, S.-H., Singh, R. P., Sinyuk, A., Schafer, J.: Aerosol properties over the Indo-Gangetic Plain: A mesoscale perspective from the TIGERZ experiment, J. Geophys. Res., 116, D18203, doi:10.1029/2011JD015809, 2011.

Gobbi, G. P., Angelini, F., Bonasoni, P., Verza, G. P., Marinoni, A., and Barnaba, F.: Sunphotometry of the 2006-2007 aerosol optical/radiative properties at the Himalayan Nepal Climate Observatory-Pyramid (5079 m a.s.1.), Atmos. Chem. Phys., 10, 11209-11221, doi:10.5194/acp-10-11209-2010, 2010.

Habib, G., Venkataraman, C., Chiapello, I., Ramachandran, S., Boucher, O., and Reddy, M. S.: Seasonal and interannual variability in absorbing aerosols over India derived from TOMS: Relationship to regional meteorology and emissions, Atmos. Environ., 40, 1909-1921, 2006.

Hegde P., Pant, P., Naja, M., Dumka, U. C., and Sagar, R.: South Asian dust episode in June 2006: Aerosol observations in the central Himalayas, Geophys. Res. Lett., 34, L23802, doi:10.1029/2007GL030692, 2007.

Hess, M., Koepke, P., and Schult, I.: Optical properties of aerosols and clouds: The software package OPAC, B. Am. Meteorol. Soc., 79, 831-844, 1998.

Holben, B. N., Eck, T. F., Slutsker, I., Tanre, D., Buis, J. P., Setzer, A., Vermote, E., Reagan, J. A., Kaufman, Y., Nakajima, T., Lavenu, F., Jankowiak, I., and Smirnov, A.: AERONET - A federated instrument network and data archive for aerosol characterization, Rem. Sens. Environ., 66, 1-16, 1998.

Holben, B. N., Eck, T. F., Slutsker, I., Smirnov, A., Sinyuk, A., Schafer, J., Giles, D., and Dubovik, O.: AERONET's Version 2.0 quality assurance criteria, 5th Asia-Pacific Remote Sensing Symposium, Goa, India, 13-17 November 2006, 6408, 2006.

Hsu, N. C., Tsay, S. C., King, M. D., and Herman, J. R.: Aerosol properties over bright-reflecting source regions, IEEE Trans. Geosci. Remote Sens., 42, 557-569, 2004.

Hsu, N. C., Tsay, S. C., King, M. D., and Herman, J. R.: Deep blue retrievals of Asian aerosol properties during ACEAsia, IEEE Trans. Geosci. Remote Sens., 44, 3180-3195, doi:10.1109/TGRS.2006.879540, 2006.

Hyvärinen, A. P., Lihavainen, H., Komppula, M., Sharma, V. P.,
Kerminen, V. M., Panwar, T. S., and Viisanen, Y.: Continuous measurements of optical properties of atmospheric aerosols in Mukteshwar, Northern India, J. Geophys. Res., 114, D08207, doi:10.1029/2008JD011489, 2009.

Ichoku, C, Levy, R., Kaufman, Y. J., Remer, L. A., Li, R. R., Martins, J. V., Holben, B. N., Abuhassan, N., Slutsker, I., Eck, T. F., and Pietras, C.: Analysis of the performance characteristics of the five-channel Microtops II Sun photometer for measuring aerosol optical thickness and precipitable water vapor, J. Geophys. Res., 107, 4179, doi:10.1029/2001JD001302, 2002.

Jethva, H., Satheesh, S. K., and Srinivasan, J.: Assessment of second-generation MODIS aerosol retrieval (Collection 005) at Kanpur, India, Geophys. Res. Lett., 34, L19802, doi:10.1029/2007GL029647, 2007.

Jethva, H., Satheesh, S. K., and Srinivasan, J.: Seasonal variability of aerosols over the Indo-Gangetic plains, J. Geophys. Res., 110, D21204, doi:10.1029/2005JD005938, 2005.

Kahn, R. A., Nelson, D. L., Garay, M., Levy, R. C., Bull, M. A., Martonchik, J. V., Diner, D. J., Paradise, S. R., Hansen, E. G., and Remer, L. A.: MISR aerosol product attributes, and statistical comparison with MODIS, IEEE Trans. Geosci. Remote Sens., 47, 4095-4114, 2009.

Kahn, R. A., Gaitley, B. J., Garay, M. J., Diner, D. J., Eck, T. F., Smirnov, A., and Holben, B. N.: Multiangle Imaging SpectroRadiometer global aerosol product assessment by comparison with the Aerosol Robotic Network, J. Geophys. Res., 115, D23209, doi:10.1029/2010JD014601, 2010.

Kalapureddy, M. C. R., Kaskaoutis, D. G., Ernest-Raj, P., Devara, P. C. S., Kambezidis, H. D., Kosmopoulos, P. G., and Nastos, P. T.: Identification of aerosol type over the Arabian Sea in the premonsoon season during the Integrated Campaign for Aerosols, Gases and Radiation Budget (ICARB), J. Geophys. Res., 114, D17203, doi:10.1029/2009JD011826, 2009.

Kaskaoutis, D. G., Kalapureddy, M. C. R., Krishna Moorthy, K., Devara, P. C. S., Nastos, P. T., Kosmopoulos, P. G., and Kambezidis, H. D.: Heterogeneity in pre-monsoon aerosol types over the Arabian Sea deduced from ship-borne measurements of spectral AODs, Atmos. Chem. Phys., 10, 4893-4908, doi:10.5194/acp-10-4893-2010, 2010.

Kaskaoutis, D. G., Kharol, S. K., Sinha, P. R., Singh, R. P., Badarinath, K. V. S., Mehdi, W., and Sharma, M.: Contrasting aerosol trends over South Asia during the last decade based on MODIS observations, Atmos. Meas. Tech. Discuss., 4, 52755323, doi:10.5194/amtd-4-5275-2011, 2011.

Kar, J., Deeter, M. N., Fishman, J., Liu, Z., Omar, A., Creilson, J. K., Trepte, C. R., Vaughan, M. A., and Winker, D. M.: Wintertime pollution over the Eastern Indo-Gangetic Plains as observed from MOPITT, CALIPSO and tropospheric ozone residual data, Atmos. Chem. Phys., 10, 12273-12283, doi:10.5194/acp-1012273-2010, 2010.

Kennedy, A. D., Dong, X., Xi, B., Xie, S., Zhang, Y., and Chen, J.: A comparison of MERRA and NARR reanalysis with the DOE ARM SGP data, J. Climate, 24, 4541-4557, 2011.

Komppula, M., Lihavainen, H., Hyvärinen, A.-P., Kerminen, V.-M., Panwar, T. S., Sharma, V. P., and Viisanen, Y.: Physical properties of aerosol particles at a Himalayan background site in India, J. Geophys. Res., 114, D12202, doi:10.1029/2008JD011007, 2009.

Kotchenruther, R. A., Hobbs, P. V., and Hegg, D. A.: Humidifica- 
tion factors for atmospheric aerosols off the mid-Atlantic coast of the United States, J. Geophys. Res., 104, 2239-2251, 1999.

Kuhlmann, J. and Quaas, J.: How can aerosols affect the Asian summer monsoon? Assessment during three consecutive premonsoon seasons from CALIPSO satellite data, Atmos. Chem. Phys., 10, 4673-4688, doi:10.5194/acp-10-4673-2010, 2010.

Kumar, R., Naja, M., Satheesh, S. K., Ojha, N., Joshi, H., Sarangi, T., Pant, P., Dumka, U. C., Hegde, P., and Venkataramani, S.: Influences of the springtime northern Indian biomass burning over the central Himalayas, J. Geophys. Res., 116, D19302, doi:10.1029/2010JD015509, 2011.

Lau, K. M., Kim, M. K., and Kim, K. M.: Asian monsoon anomalies induced by aerosol direct effects, Clim. Dyn., 26, 855-864, doi:10.1007/s00382-006-0114-z, 2006.

Lau K.-M. and Kim, K.-M.: Observational relationships between aerosol and Asian monsoon rainfall, and circulation, Geophys. Res. Lett., 33, L21810, doi:10.1029/2006GL027546, 2006.

Lau, K. M., Ramanathan, V., Wu, G.-X., Li, Z., Tsay, S. C., Hsu, C., Sikka, R., Holben, B., Lu., D., Tartari, G., Chin, M., Koudelova, P., Chen, H., Ma, Y., Huang, J., Taniguchi, K., and Zhang, R.: The Joint Aerosol-Monsoon Experiment - A new challenge for monsoon climate research, B. Am. Meteorol. Soc., 89, 369-383, doi:10.1175/BAMS-89-3-369, 2008.

Lau, K. M., Kim, M. K., Kim, K. M., and Lee, W. S.: Enhanced surface warming and accelerated snow melt in the Himalayas and Tibetan Plateau induced by absorbing aerosols, Env. Res. Lett., 5, 025204, doi:10.1088/1748-9326/5/2/025204, 2010.

Lau, W. K. M. and Kim, K.-M.: Fingerprinting the impacts of aerosols on long-term trends of the Indian summer monsoon regional rainfall, Geophys. Res. Lett., 37, L16705, doi:10.1029/2010GL043255, 2010.

Lawrence, M. G. and Lelieveld, J.: Atmospheric pollutant outflow from Southern Asia: a review, Atmos. Chem. Phys., 10, 1101711096, doi:10.5194/acp-10-11017-2010, 2010.

Levy, R. C., Remer, L. A., Mattoo, S., Vermote, E. F., and Kaufman, Y. J.: Second-generation operational algorithm: Retrieval of aerosol properties over land from inversion of Moderate Resolution Imaging Spectroradiometer spectral reflectance, J. Geophys. Res., 112, D13211, doi:10.1029/2006JD007811, 2007.

Marcq, S., Laj, P., Roger, J. C., Villani, P., Sellegri, K., Bonasoni, P., Marinoni, A., Cristofanelli, P., Verza, G. P., and Bergin, M.: Aerosol optical properties and radiative forcing in the high Himalaya based on measurements at the Nepal Climate Observatory-Pyramid site (5079 m a.s.1.), Atmos. Chem. Phys., 10, 5859-5872, doi:10.5194/acp-10-5859-2010, 2010.

Marinoni, A., Cristofanelli, P., Laj, P., Duchi, R., Calzolari, F., Decesari, S., Sellegri, K., Vuillermoz, E., Verza, G. P., Villani, P., and Bonasoni, P.: Aerosol mass and black carbon concentrations, a two year record at NCO-P (5079 m, Southern Himalayas), Atmos. Chem. Phys., 10, 8551-8562, doi:10.5194/acp-10-85512010, 2010.

Meehl, G. A., Arblaster, J. M., and Collins, W. D.: Effects of black carbon aerosols on the Indian monsoon, J. Clim., 21, 2869-2882, 2008.

Menon, S., Hansen, J., Nazarenko, L., and Luo, Y., Climate effects of black carbon aerosols in China and India, Science, 297, 22502253, 2002.

Ming, J., Cachier, H., Xiao, C., Qin, D., Kang, S., Hou, S., and $\mathrm{Xu}$, J.: Black carbon record based on a shallow Himalayan ice core and its climatic implications, Atmos. Chem. Phys., 8, 13431352, doi:10.5194/acp-8-1343-2008, 2008.

Moorthy, K. K., Babu, S. S., Satheesh, S. K., Srinivasan, J., and Dutt, C. B. S.,: Dust absorption over the "Great Indian Desert" inferred using ground-based and satellite remote sensing, J. Geophys. Res., 112, D09206, doi:10.1029/2006JD007690, 2007.

Pant, P., Hegde, P., Dumka, U. C., Sagar, R., Satheesh, S. K., Moorthy, K. K., Saha, A., and Srivastava, M. K.: Aerosol characteristics at a high-altitude location in central Himalayas: Optical properties and radiative forcing, J. Geophys. Res., 111, D17206, doi:10.1029/2005JD006768, 2006.

Prasad, A. K. and Singh, R. P.: Changes in aerosol parameters during major dust storm events (2001-2005) over the Indo-Gangetic Plains using AERONET and MODIS data, J. Geophys. Res., 112, D09208, doi:10.1029/2006JD007778, 2007.

Pandithurai, G., Dipu, S. , Dani, K. K., Tiwari, S., Bisht, D. S., Devara, P. C. S., and Pinker, R. T.: Aerosol radiative forcing during dust events over New Delhi, India, J. Geophys. Res., 113, D13209, doi:10.1029/2008JD009804, 2008.

Pathak, B., Kalita, G., Bhuyan, K., Bhuyan, P. K., and Moorthy, K. K.: Aerosol temporal characteristics and its impact on shortwave radiative forcing at a location in the Northeast of India, J. Geophys. Res., 115, D19204, doi:10.1029/2009JD013462, 2010.

Prospero, J. M., Ginoux, P., Torres, O., Nicholson, S. E., and Gill, T. E.: environmental characterization of global sources of atmospheric soil dust identified with the Nimbus 7 Total Ozone Mapping Spectrometer (TOMS) absorbing aerosol product, Rev. Geophys., 40, 1002, doi:10.1029/2000RG000095, 2002.

Qian, Y., Flanner, M. G., Leung, L. R., and Wang, W.: Sensitivity studies on the impacts of Tibetan Plateau snowpack pollution on the Asian hydrological cycle and monsoon climate, Atmos. Chem. Phys., 11, 1929-1948, doi:10.5194/acp-11-1929-2011, 2011.

Ram, K., Sarin, M. M., and Hegde, P.: Long-term record of aerosol optical properties and chemical composition from a high-altitude site (Manora Peak) in Central Himalaya, Atmos. Chem. Phys., 10, 11791-11803, doi:10.5194/acp-10-11791-2010, 2010.

Ramachandran, S. and Kedia, S.: Black carbon aerosols over an urban region: Radiative forcing and climate impact, J. Geophys. Res., 115, D10202, doi:10.1029/2009JD013560, 2010.

Ramanathan, V., Chung, C., Kim, D., Bettge, T., Buja, L., Kiehl, J. T., Washington, W. M., Fu, Q., Sikka, D. R., and Wild, M.: Atmospheric brown clouds: Impacts on South Asian climate and hydrological cycle, Proc. Natl. Acad. Sci. USA, 102, 5326-5333, 2005.

Ramanathan, V. and Carmichael, G.: Global and regional climate changes due to black carbon, Nat. Geosci., 1, 221-227, doi:10.1038/ngeo156, 2008.

Randles, C. A. and Ramaswamy, V.: Absorbing aerosols over Asia: A Geophysical Fluid Dynamics Laboratory general circulation model sensitivity study of model response to aerosol optical depth and aerosol absorption, J. Geophys. Res., 113, D21203, doi:10.1029/2008JD010140, 2008.

Remer, L. A., Kaufman, Y. J., Tanr'e, D., Mattoo, S., Chu, D. A., Martins, J. V., Li, R.-R., Ichoku, C., Levy, R. C., Kleidman, R. G., Eck, T. F., Vermote, E., and Holben, B. N.: The MODIS aerosol algorithm, products and validation, J. Atmos. Sci., 62, 947-973, 2005.

Rienecker, M. M., Suarez, M. J., Todling, R., Bacmeister, J., 
Takacs, L., Liu, H.-C., Gu, W., Sienkiewicz, M., Koster, R. D., Gelaro, R., Stajner, I., and Nielsen, J. E.: The GEOS-5 Data Assimilation System - Documentation of Versions 5.0.1, 5.1.0, and 5.2.0, NASA/TM-2008-104606, Vol. 27, 101 pp, 2008.

Rienecker, M. M., Suarez, M. J., Gelaro, R., Todling, R., Bacmeister, J., Liu, R., Bosilovich, M. G., Schubert, S. D., Takacs, L., Kim, G-K, Bloom, S., Chen, J., Collins, D., Conaty, A., da Silva, A., Gu, W., Joiner, J., Koster, R. D., Lucchesi, R., Molod, A., Owens, T., Pawson, S., Pegion, P., Redder, C. R., Reichle, R., Robertson, F. R., Ruddick, A. G., Sienkiewicz, M., and Woollen, J.: MERRA: NASA's Modern-Era Retrospective Analysis for Research and Applications, J. Climate, 24, 3624-3648, 2011.

Rood, M. J., Covert, D. S., and Larson, T. V.: Hygroscopic properties of atmospheric aerosol in Riverside, California, Tellus-B, 39, 383-397, 1987.

Rutan, D., Rose, F., Roman, M., Manalo-Smith, N., Schaaf, C., and Charlock, T.: Development and assessment of broadband surface albedo from Clouds and the Earth's Radiant Energy System Clouds and Radiation Swath data product, J. Geophys. Res., 114, D08125, doi:10.1029/2008JD010669, 2009.

Satheesh, S. K. and Srinivasan, J.: Enhanced aerosol loading over Arabian Sea during the pre-monsoon season: Natural or anthropogenic?, Geophys. Res. Lett., 29, 1874, doi:10.1029/2002GL015687, 2002.

Satheesh, S. K., Deepshikha, S., Srinivasan, J., and Kaufman, Y. J.: Large Dust Absorption of Infrared Radiation over Afro-Asian Regions: Evidence for Anthropogenic Impact, IEEE Geosci. Rem. Sens. Lett., 111, D08202, doi:10.1029/2005JD006374, 2006.

Satheesh, S. K., Moorthy, K. K., Babu, S. S., Vinoj, V., and Dutt, C. B. S.: Climate implications of large warming by elevated aerosol over India, Geophys. Res. Lett., 35, L19809, doi:10.1029/2008GL034944, 2008.

Schafer, J. S., Eck, T. F., Holben, B. N., Artaxo, P., Yamasoe, M. A., and Procopio, S.: Observed reductions of total solar irradiance by biomass-burning aerosols in the Brazilian Amazon and Zambian Savanna, Geophys. Res. Lett., 29, 1823, doi:10.1029/2001GL014309, 2002.

Schmid, B., Michalsky, J. J., Slater, D. W., Barnard, J. C., Halthore, R. N., Liljegren, J. C., Holben, B. N., Eck, T. F., Livingston, J. M., Russell, P. B., Ingold, T., and Slutske, I.: Comparison of columnar water-vapor measurements from solar transmittance methods, Appl. Opt., 40, 1886-1896, doi:10.1364/AO.40.001886, 2001.

Shrestha, P., Barros, A. P., and Khlystov, A.: Chemical composition and aerosol size distribution of the middle mountain range in the Nepal Himalayas during the 2009 pre-monsoon season, Atmos. Chem. Phys., 10, 11605-11621, doi:10.5194/acp-1011605-2010, 2010.

Singh R. P., Dey, S., Tripathi, S. N., Tare, V., and Holben, B.: Variability of aerosol parameters over Kanpur, northern India, J. Geophys. Res., 109, D23206, doi:10.1029/2004JD004966, 2004.

Singh, S., Nath, S., Kohli, R., and Singh, R.: Aerosols over Delhi during pre-monsoon months: Characteristics and effects on surface radiation forcing, Geophys. Res. Lett., 32, L13808, doi:10.1029/2005GL023062, 2005.
Singh, S., Soni, K., Bano, T., Tanwar, R. S., Nath, S., and Arya, B. C.: Clear-sky direct aerosol radiative forcing variations over mega-city Delhi, Ann. Geophys., 28, 1157-1166, doi:10.5194/angeo-28-1157-2010, 2010.

Smirnov, A., Holben, B. N., Eck, T. F., Dubovik, O., and Slutsker, I.: Cloudscreening and quality control algorithms for the AERONET database, Rem. Sens. Environ., 73, 337-349, 2000.

Smirnov, A., Holben, B. N., Lyapustin, A., Slutsker, I., and Eck, T. F.: AERONET processing algorithm refinement, AERONET Workshop, El Arenosillo, Spain, 10-14 May, 2004.

Smirnov, A., Holben, B. N., Eck, T. F., Slutsker, I., Chatenet, B., and Pinker, R. T.: Diurnal variability of aerosol optical depth observed at AERONET (Aerosol Robotic Network) sites, Geophys. Res. Lett., 29, 2115, doi:10.1029/2002GL016305, 2002.

Smirnov, A., Holben, B. N., Slutsker, I., Giles, D. M., McClain, C. R., Eck, T. F., Sakerin, S. M., Macke, A., Croot, P., Zibordi, G., Quinn, P. K., Sciare, J., Kinne, S., Harvey, M., Smyth, T. J., Piketh, S., Zielinski, T., Proshutinsky, A., Goes, J. I., Nelson, N. B., Larouche, P., Radionov, V. F., Goloub, P., Moorthy, K. K., Matarrese, R., Robertson, E. J., and Jourdin, F.: Maritime Aerosol Network as a component of Aerosol Robotic Network, J. Geophys. Res., 114, D06204, doi:10.1029/2008JD011257, 2009.

Soni, K., Singh, S., Bano, T., Tanwar, R.S., Nath, S., Arya, B.C.: Variations in single scattering albedo and Angstrom absorption exponent during different seasons at Delhi, India, Atmospheric environment, 44, 4355-4363, doi:10.1016/j.atmosenv.2010.07.058, 2010.

Srivastava, A. K., Tiwari, S., Devara, P. C. S., Bisht, D. S., Srivastava, Manoj K., Tripathi, S. N., Goloub, P., and Holben, B. N.: Pre-monsoon aerosol characteristics over the Indo-Gangetic Basin: implications to climatic impact, Ann. Geophys., 29, 789804, doi:10.5194/angeo-29-789-2011, 2011.

Sud, Y. C., Wilcox, E., Lau, W. K.-M., Walker, G. K., Liu, X.H., Nenes, A., Lee, D., Kim, K.-M., Zhou, Y., and Bhattacharjee, P. S.: Sensitivity of boreal-summer circulation and precipitation to atmospheric aerosols in selected regions Part 1: Africa and India, Ann. Geophys., 27, 3989-4007, doi:10.5194/angeo27-3989-2009, 2009

Wang, C., Kim, D., E kman, A. M. L., Barth, M. C., and Rasch, P. J.: Impact of anthropogenic aerosols on Indian summer monsoon, Geophys. Res. Lett., 36, L21704, doi:10.1029/2009GL040114, 2009.

Wong, S., Fetzer, E. J., Kahn, B. H., Tian, B., Lambrigtsen, B. H., and Ye, H.: Closing the global water vapor budget with AIRS water vapor, MERRA reanalysis, TRMM and GPCP precipitation, and GSSTF surface evaporation, J. Climate, doi:10.1175/2011JCLI4154.1, 24, 6307-6321, 2011.

Yasunari, T. J., Bonasoni, P., Laj, P., Fujita, K., Vuillermoz, E., Marinoni, A., Cristofanelli, P., Duchi, R., Tartari, G., and Lau, K.-M.: Estimated impact of black carbon deposition during premonsoon season from Nepal Climate Observatory - Pyramid data and snow albedo changes over Himalayan glaciers, Atmos. Chem. Phys., 10, 6603-6615, doi:10.5194/acp-10-6603-2010, 2010. 